\title{
THE INTERTIDAL ECOLOGY OF SELECTED LOCALITIES IN THE PLYMOUTH NEIGHBOURHOOD
}

\author{
By Ronald G. Evans
}

Department of Zoology, University College of Wales, Aberystwyth

(Text-figs. I-I4)

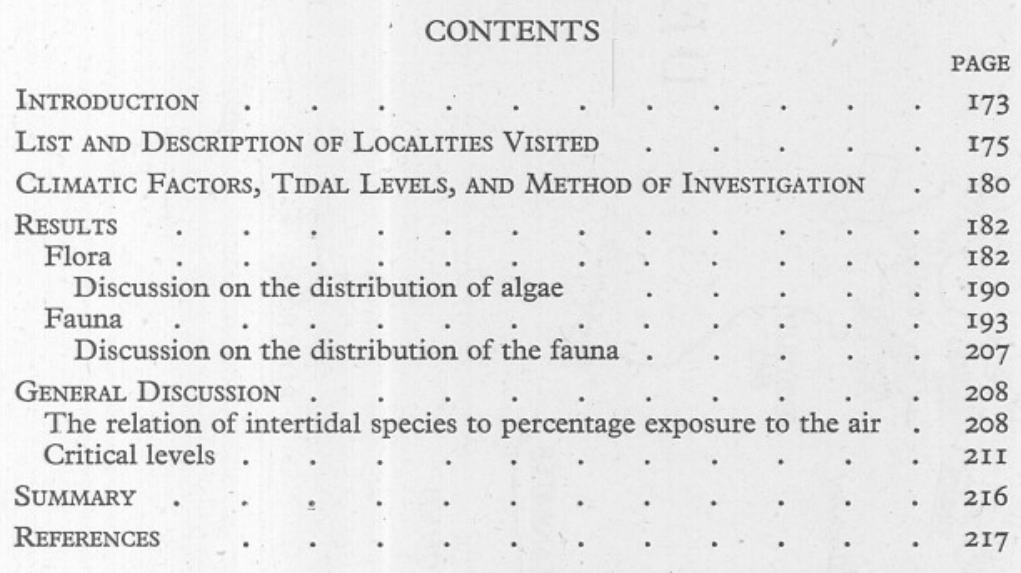

\section{INTRODUCTION}

The importance of surf action, both as a presence or absence factor and as a modifying influence on the nature of littoral distribution, has been demonstrated during a survey of intertidal conditions in Cardigan Bay (Evans, 1947). The coast of mid-Wales, however, is comparatively smooth in outline, and offers little variation in exposure to or shelter from wave-action; consequently it was decided to confirm and amplify certain features of the previous study by the investigation of a much more irregular coastline in the neighbourhood of Plymouth. Here (see Fig. I) the nature of the coastline is such that localities exposed to maximum wave action and localities almost completely sheltered from surf both occur within a short distance of each other. The extent to which wash, splash, and spray, resulting from heavy surf, may modify the vertical ranges of intertidal plants and animals is known in a general way only; it is here proposed to treat this problem with more attention than it has hitherto received, and to record, if possible, the actual extent to which such modifications may be observed. It is known that splash and spray, by raising the effective (in distinction to the predicted) level of tides, both tend to raise 


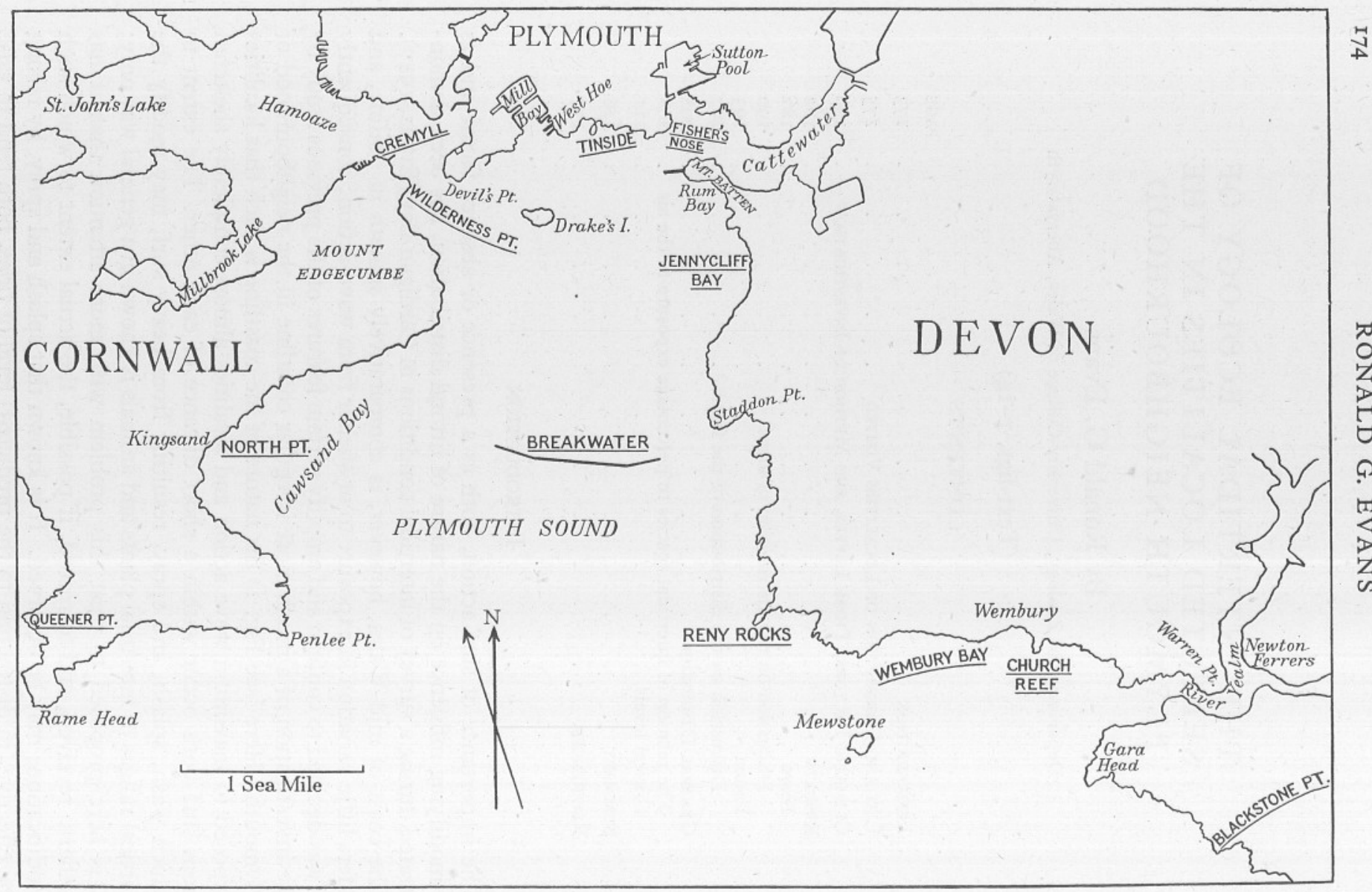

Fig. I. Map showing localities included in the survey. (After Plymouth Marine Fauna, I93I.) 
the upper limit of certain species with regard to predicted tidal levels. Moore (I935a) has shown that surf also has a lowering effect on the lower limit of Balanus balanoides, but whether similar effects may be distinguished in other species remains uninvestigated, and it is proposed to consider this possibility.

Furthermore the existence of 'critical levels' will be examined. It was found (Evans, I947) that such levels in Cardigan Bay appear to be rather different in position from those described by Colman (I933) as being critical for species on Church Reef, Wembury, and before a true comparison could be made it was decided that this latter area must be restudied more extensively than Colman's traverse-method made possible. Moreover, the position of such critical levels under different local conditions (e.g. of surf action and rock-configuration) is likely to prove interesting.

Finally, by making an extensive study of Church Reef, and comparing the results with those obtained by Colman (I933), it will be possible to obtain some idea of the extent to which the study of a few detailed traverses can give an average picture of distribution in such an area.

The work was carried out in the summer of I946; twelve localities in the Plymouth region were selected, and the distributions of some of the common plant and animal species were examined and described at each locality.

\section{LisT AND DESCRIPTION OF LOCALITIES VISITED}

These are all shown in the map (Fig. I), with the exception of Fort Charles and Bolt Head, which lie in the Salcombe estuary, almost 20 miles to the east of Plymouth Sound.

Bolt Head. This lies on the west of the entrance to Salcombe estuary and is open to winds and waves from any quarter between east and west. Even when the wind is not strong the swell is appreciable, and the wash, splash, and spray zones are quite extensive. The cliff face is high and the rocks slope steeply down to low water, these slopes generally facing south-south-west and receiving both maximum surf and maximum illumination. Near low-water mark the steep faces tend to flatten out horizontally in some places. Very little loose material occurs, except for a few large boulders or slabs which are occasionally found wedged in narrow crevices.

Blackstone Point. Just east of Gara Head (see Fig. I), this is open to the sea from west to east-south-east, with some little protection on the east from Revelstoke Point and other points on the peninsula. High jagged ridges of Dartmouth Slate slope almost vertically to low water, sometimes from a height of over $50 \mathrm{ft}$. above chart datum. Deep fissures, running approximately north-south, occur between the slate laminae, which present almost sheer faces to the east and west. Here again considerable surf action is experienced.

Reny Rocks. This group of rocks, on the east side of the entrance to Plymouth Sound, is exposed to winds between west and east-south-east. Moreover, 
Rame Head lies some distance away on the west, and its sheltering effect is small; the same is true of Gara Head and the Mewstone on the east and southeast. The locality is almost as fully exposed, therefore, as Bolt Head or Blackstone Point. Reny Rocks consists of a group of irregular, steep-sided peaks, rising to over $40 \mathrm{ft}$. above low water, and separated from the mainland by a low-lying stretch of boulders which dries out at mean low water of neaps. (Owing to the inaccessibility of the Rocks except at low water, this area was not investigated as thoroughly as the other localities.)

Queener Point. Rame Head itself was inaccessible owing to the presence of anti-invasion defences, consequently Queener Point, on its north side, was chosen for investigation. This is less exposed than Rame Head itself or than Bolt Head, Blackstone Point, or Reny Rocks, being open to the sea only from south to west-north-west. However, the rocks are steep and jagged, rising to 30-40 ft. above chart datum, and running approximately north-east to southwest; and since the swell is usually heavy, a considerable amount of wash, splash, and spray is experienced. Large pebbles and boulders occur in the gullies between the rocky promontories, and on the north and north-west sides of the Point the steep rock levels out to a horizontal stretch just below mean tide level.

Plymouth Breakwater. An artificial structure, lying across the entrance to the Sound, at approximately 2 miles from the mainland, this is composed of limestone blocks, with large masses of rough concrete in front. These concrete masses are cubical blocks, IO-I2 ft. square, with their bases at low water. They are separated from each other by approximately 6 yards, and from the south slope of the Breakwater by about I 5 yards of a fairly level stretch of loose limestone blocks with boulders wedged between them. The whole Breakwater is described in detail by Lysaght (194I). An area in the centre was chosen for investigation, including about 30 yards of the south and north slopes, the top, the sheltering blocks and the level area behind these. The locality is open from south-west to south-east, with some protection outside this quadrant from Penlee and Reny Points. Wave action is strong on the south slope, but the protecting blocks afford some shelter to the lower part of this slope. The north side is, in comparison, fairly sheltered.

Tinside to West Hoe. Here the rocks are of limestone, broken and fissured and generally descending rather steeply to low water. The surface is pitted with the holes of boring organisms (e.g. Saxicava rugosa), and depressions and rock pools are frequent. Caves and inlets occur along the front, and the natural line of the rocks is interrupted by artificially built concrete walls, steps, quays, etc. Pebbles and boulders are present in coves and channels. The Breakwater, lying about 2 miles offshore, gives comparatively little shelter and a heavy swell is common in the waters of the Sound when the wind is in the south. This, combined with the steep slope of the Tinside rocks, makes for fairly heavy wave shock, but the area is less exposed than those previously 
described. Towards the east end, in the Fisher's Nose region, the shelter of Mount Batten breakwater (about a quarter of a mile south) begins to be felt, also the shore is less steep here, and the surf is mitigated to some extent.

Church Reef, Wembury. Colman (I933) studied only the landward portion of this locality, but the present survey also includes the steep seaward reefs and ridges. The area is very irregular, the angle of dip of the rocks is generally steep and the slopes face seaward, but this is variable. High peaks, which are not completely submerged even at high springs, occur on the south and southeast, but on the north, north-west and north-east corner the general lie of the shore is lower and more regular. The centre of the Reef is occupied by high peaks (e.g. Colman's 'Central Rock'). Pools, inlets, and channels are frequent, often containing shingle and gravel, but large boulders are not common. At the top of the shore the cliff face is low and is footed by shingle on the west, but on the east the shingle disappears and a mass of steep rocks occurs (through which runs Colman's 'Traverse D'). As a whole Church Reef may be described as moderately exposed to surf, receiving some shelter on the west from Reny and Wembury Points, on the south-west from the Mewstone, and on the east from Gara Head. Local variation in wave action is experienced; the south faces of the low-tide reefs are battered by heavy surf, but they create some shelter for the more landward portion of the area.

North Point. This lies just east of Kingsand village on the west side of Plymouth Sound, and the area faces almost due south-east. The rocks are felsite, weathering into rounded contours, with few deep fissures, unlike the Mica-schists of Bolt Head, for example. The beach is much more regular than it is at any of the other stations, and the slope is fairly even, while no peaks or high ridges are present, and vertical faces are occasional only. Gravel and shingle are present in pools and gullies. Penlee Point, on the south, provides some shelter, so does Reny Point on the east-south-east, but North Point is open to the sea between these two headlands. It may be described as moderately exposed to surf, and the regularity of the rock formation reduces the range of variation in shelter and surf action.

Fennycliff Bay. This is an area on the east side of Plymouth Sound, between Rum Bay on the north and Ram's Cliff on the south. The strata of Staddon Grits weather into small but steep headlands, with intervening areas of lower rock. In these low-lying areas occur boulders and small loose masses from the cliff face, while sand and gravel are present locally. The general dip of the rocks is seaward, but this varies. Though actually enclosed from the open sea on all sides, Jennycliff Bay is not very sheltered; the west side of the Sound and the Breakwater both lie some distance away, and surf action is strong when the wind is in the south, west or south-west. Local variation is again experienced; the level areas are protected by the headlands, and the south and south-west aspects of higher rocks receive the maximum of wave shock. In general, the area may again be considered as moderately exposed. 
Fort Charles, Salcombe. This lies just south of Salcombe village on the west side of Salcombe estuary, and faces almost due south. Two distinct areas were investigated here; Fort Charles east and Fort Charles west. On the east side (i.e. Fort Charles east) the high cliff face descends steeply to a narrow shingle beach which, a few yards further seaward, rises sharply to a high mass of rocks on which stands a ruined fort. In front of this ruin the rock steps irregularly down to about high-water neaps level, then drops perpendicularly to low water. Offshore, a few small reefs of lower rock occur. On the west side (Fort Charles west) the cliff descends to a jumbled mass of loose rock, passing into a zone of low-lying ledges with scattered boulders, which continues about 50 yards to low water. Here there are no peaks or steep-sided rocky masses of any size. The whole of the Fort Charles locality is open to the sea only between south-south-west and south-south-east; moreover, the shallow estuary and large sandbanks also tend to reduce the violence of surf. However, the high steep rocks of Fort Charles east are more subject to wave shock than the comparatively level shore of Fort Charles west.

Wilderness Point. This is an area just east of the Cremyll landing stage, facing slightly east of north. The rock is a continuation of the Plymouth limestone, and similar to it in texture. The shore is backed by a high stone wall, and the upper beach just below this consists of rocky peaks, 4 or $5 \mathrm{ft}$. high, surrounded by shingle. Proceeding down the beach shingle becomes less abundant and the rocks flatter and more regular. The area is enclosed from the open sea on all sides, and neither surf nor swell is experienced to any appreciable extent. The water is laden with suspended material brought down the Hamoaze, and fucoids tend to trap and filter this, and to lay a deposit of fine silt over the rocks of Wilderness Point.

Warren Point. This area lies on the north bank of the river Yealm, about a mile east of Church Reef, and faces south. The cliff face is very low and drops to a stony beach with patches of mud and silt. In places rock ledges protrude through the shingle to as low as extreme high-water neaps level, but usually the rock is covered by shingle from above this level down to low water. The locality is enclosed from the open sea on all sides, and wave action is at minimum; although the beach is stony, the pebbles are not liable to much movement, and are sufficiently stable to support several plant and animal species.

In addition to the foregoing localities which were studied in detail, notes were also taken at other points on the shore, e.g. in Wembury Bay, at Cremyll, at Newton Ferrers, etc.

It is unfortunate that there exists no adequate means of measuring the degree of exposure to wave action to which various localities may be subjected. Moore (I935 a) has attempted to do this on a basis of 'the number of days per hundred days in which any wind blows into the exposed aperture of the locality in question'. While this may give some indication of the maximum exposure which can be expected at a given station on the coast, there exists, within each 
locality, such a degree of variation that the method becomes impracticable in a survey such as the present one. Within an irregular formation of rock such as Church Reef, for instance, some rock faces (e.g. the south faces of the seaward reefs) will be as exposed to surf almost as heavy as that experienced at Bolt Head, while other stretches in the same locality (e.g. flat rocks to the leeward of high ridges) will be as sheltered from the full force of the waves as the shore of Wilderness Point, for example. So many factors combine to produce this variation that it is impossible to derive any satisfactory expression of relative wave-exposure on a given surface. Taking into account the orientation of the rock with regard to the waves and the direction of the prevailing winds, the angle of slope, its proximity to sheltering masses, and its position with regard to tidal levels (see later), it is, however, possible to form some idea of the exposure to which a small area is likely to be subjected. The twelve localities listed above are arranged in order of increasing shelter, the list given in Table I

Table I. List of Stations Numbered in Figs. 3-I2 ArRanged in ORDER OF DECREASING EXPOSURE TO WAVE ACTION

\footnotetext{
1. Bolt Head. Vertical south face

2. Reny Rocks. Vertical south face

3. Blackstone Point. Vertical east and south-east faces

4. Queener Point. Vertical south face

5. Blackstone Point. $50^{\circ}$ slope facing east

6. Church Reef. South face of seaward reefs

7. Breakwater. South slope

8. Bolt Head. Horizontal rocks

9. Queener Point. Horizontal rocks

10. Blackstone Point. North-west face

11. Bolt Head. North-east overhang

12. Church Reef. North face of seaward reefs

13. Jennycliff Bay. Vertical south and south-west faces

14. Tinside. Vertical south face

15. Blow-hole in Wembury Bay

16. Church Reef. Landward rocks

17. Church Reef. Protected south face

18. Church Reef. Flat rocks on north-east

19. North Point. East end

20. Jennycliff Bay. $70^{\circ}$ slope, facing east

21. Breakwater. North face

22. Tinside. $40^{\circ}$ slope, facing south

23. Fort Charles. East

24. Jennycliff Bay. North face and overhangs

25. Bolt Head. Cave

26. Jennycliff Bay. Flat rocks

27. Fort Charles. West

28. Breakwater. Corner on north face

29. Tinside. Horizontal rocks

3o. Tinside. Fisher's Nose region

31. North Point. West end

32. Wembury Bay. Sheltered south face

33. Wembury Bay. North face

34. Cremyll

35. Wilderness Point

36. Warren Point

37. Newton Ferrers

'Very exposed'

'Exposed'

'Semi-exposed'

'Sheltered'

'Very sheltered'
} 
includes all the areas quoted in the paper and indicated by number (e.g. [26]) in Figs. $3^{-12}$; these also are arranged in order of decreasing exposure (based on the considerations cited above), and, for convenience, have been classified into five categories, 'very exposed', 'exposed', 'semi-exposed', 'sheltered', and 'very sheltered'.

\section{Climatic Factors, Tidal Levels, and Method of Investigation}

The climate of Plymouth is mild, and typical of south-west England in general. According to Lysaght (I94I), on an average $33 \%$ of the winds blow from between south-west and south-east, i.e. from the Channel and from the open Atlantic. Thus, as in Cardigan Bay, the main exposure is from a southerly direction, but from personal observation it is confirmed that such headlands as Bolt Head, Blackstone Point, Reny Point, and Queener Point, are very much more surf-beaten than any locality in the middle of Cardigan Bay. On the other hand, both Wilderness and Warren Points receive far more shelter from waves than any locality on the coast of mid-Wales.

Tidal data are taken from those given for Devonport in the Admiralty Tide Tables, Sect. A, Pt. I, and values for extreme springs and neaps are means for the Io years I937-46. The Devonport figures are taken as applicable for all localities except Bolt Head and Fort Charles; for these, the corrections for Salcombe tides are applied. Table II gives the tidal scales for both Plymouth and Salcombe localities, but in the following text-figures the zonations at Bolt Head and Fort Charles are interpolated (with the necessary corrections) on the Plymouth scale, for purposes of comparison. All heights are given as feet above or below Chart Datum which, at Devonport, lies $8.42 \mathrm{ft}$. below Ordnance Datum.

\section{TABLE II. TIDAL SCALES}

(Heights are given as feet above or below Chart datum)

$\begin{array}{lcc}\text { Tidal level } & \begin{array}{c}\text { Plymouth } \\ \text { (ft.) }\end{array} & \begin{array}{c}\text { Salcombe } \\ (\mathrm{ft} .)\end{array} \\ \text { E.H.W.s. } & \mathrm{I} 7 & \mathrm{I7 \cdot 3} \\ \text { M.H.W.S. } & \mathrm{I5} \cdot 7 & \mathrm{I} 6 \\ \text { M.H.W.N. } & \mathrm{I} \cdot 3 & \mathrm{I} \cdot 6 \\ \text { E.H.W.N. } & \mathrm{IO} & \mathrm{IO} \cdot 3 \\ \text { M.T.L. } & 8 \cdot 2 & 8 \cdot 8 \\ \text { E.L.W.N. } & 5 \cdot 7 & 6 \cdot 6 \\ \text { M.L.W.N. } & 4 \cdot 6 & 5 \cdot 5 \\ \text { M.L.W.S. } & 0 \cdot 2 & \mathrm{I} \cdot \mathrm{I} \\ \text { E.L.W.S. } & -\mathrm{I} \cdot 6 & -0 \cdot 7\end{array}$

The species selected for attention are those studied in the Cardigan Bay survey (Evans, I947), but Himanthalia lorea (de la Pyl) and Balanus perforatus Brugière are additional. Sabellaria alveolata (L.), which is not general in the Plymouth neighbourhood, is omitted. 
Methods similar to those adopted in the previous survey were followed, i.e. tidal levels were marked by observation of the water-level at different times between high and low water, and zonation was studied by walking along the shore and taking notes, parallel to the water-line, first at one level and then at another as the tide ebbed. In view of the limited period available for the work one innovation was introduced; advantage was taken of an early period of calm weather to mark reference levels at as many stations as possible, the time of marking of the water-level being noted and its height being calculated by using Supplementary Table I of the A.T.T., Sect. A, Pt. I. This procedure has the following advantages. (a) Providing that all the localities are marked during one day or during days of similar conditions of wind and tides, then any error in the height of the marked levels will tend to be a constant one, for comparative purposes. The Breakwater, Queener Point, North Point, Wilderness Point, and Jennycliff Bay were all marked during one calm day, and Tinside in the late evening of the same day. Reny Rocks, Church Reef and Warren Point were visited on the following day. A break in the weather delayed the marking of Blackstone Point until a fortnight later, while Fort Charles and Bolt Head were marked on successive days at the same period. (b) Having once established such reference points during calm weather, the areas could be studied even when the condition of the sea was not ideal; the actual height of the tide, at the calculated time when it should arrive at the mark, could be checked with reference to this mark, and an approximate estimate of any error due to wind or swell could be made.

The efficiency of this method of assessing vertical heights on the shore and the zonation of species may be judged by comparing results obtained for the zonation of the algae on Church Reef with similar figures obtained from a study of the same area from detailed levelled traverses by Colman (1933). This comparison is made in Fig. 2; it should be noted that the writer has deducted Colman's 'splash allowance' of $2 \mathrm{ft}$., and has also based the zonation on the tidal scale given in Table I (i.e. using ro-year means for extreme neaps and springs). There is a surprising measure of agreement, though certain points demand comment. While my limits for the 'zones of abundance' of Pelvetia, Fucus spiralis, and Ascophyllum nodosum agree closely with Colman's 'mean limits' of distribution (I933, p. 454, table IV), my absolute limits of distribution are more extended than the latter's 'extreme limits'. Especially is this so for Pelvetia and Fucus spiralis, both of which, it should be noticed, are zoned by Colman on one traverse only (Traverse D); for Ascophyllum and Fucus serratus, which he zones on two traverses, the differences are less marked. This appears to be the natural result of a more extensive and broader survey; but, allowing for this, the direct observational study of tide levels and the basing of vertical zonations on this would seem to be at least as accurate as any method based on the detailed examination of surveyed traverses. This is further indicated by the general consistency of the results which the writer has 
obtained in different areas, both on the coast of mid-Wales and in the Plymouth locality. Thus, if the necessary precautions with regard to calm conditions are observed, the method appears to be fully justifiable, and possesses undoubted advantages for this type of survey.

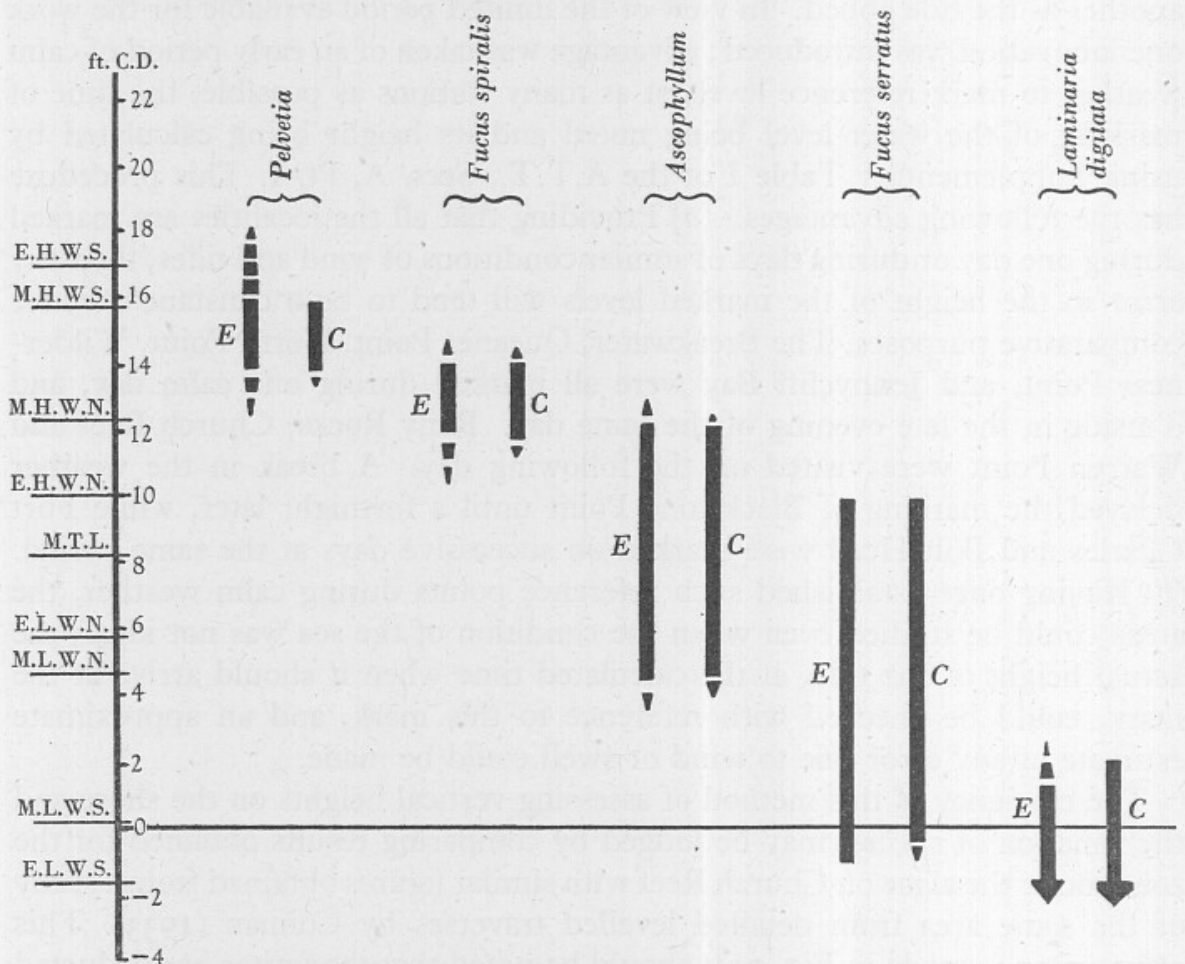

Fig. 2. Comparison of algal zonation on Church Reef, Wembury, with results obtained by Colman (1933). E, present results; $C$, Colman's data.

Note. In Figs. 2-I4 inclusive the same scale is used for vertical heights above or below chart datum.

\section{RESULTS}

The general features of the horizontal distribution of the species studied (with the exception of Himanthalia lorea and Balanus perforatus) as they occur in Cardigan Bay have been fully discussed in my earlier paper, together with the effects of wave action and other factors on this distribution. The present investigation confirms many of these observations, which it is unnecessary to repeat here, except where any significant differences have been noted.

\section{Flora}

Pelvetia canaliculata Dcne. \& Thur. This is entirely absent from Bolt Head, and represented only as occasional and very stunted plants at Blackstone, Reny, Queener, the Breakwater, and Tinside. A sparse and scattered Pelvetia zone 

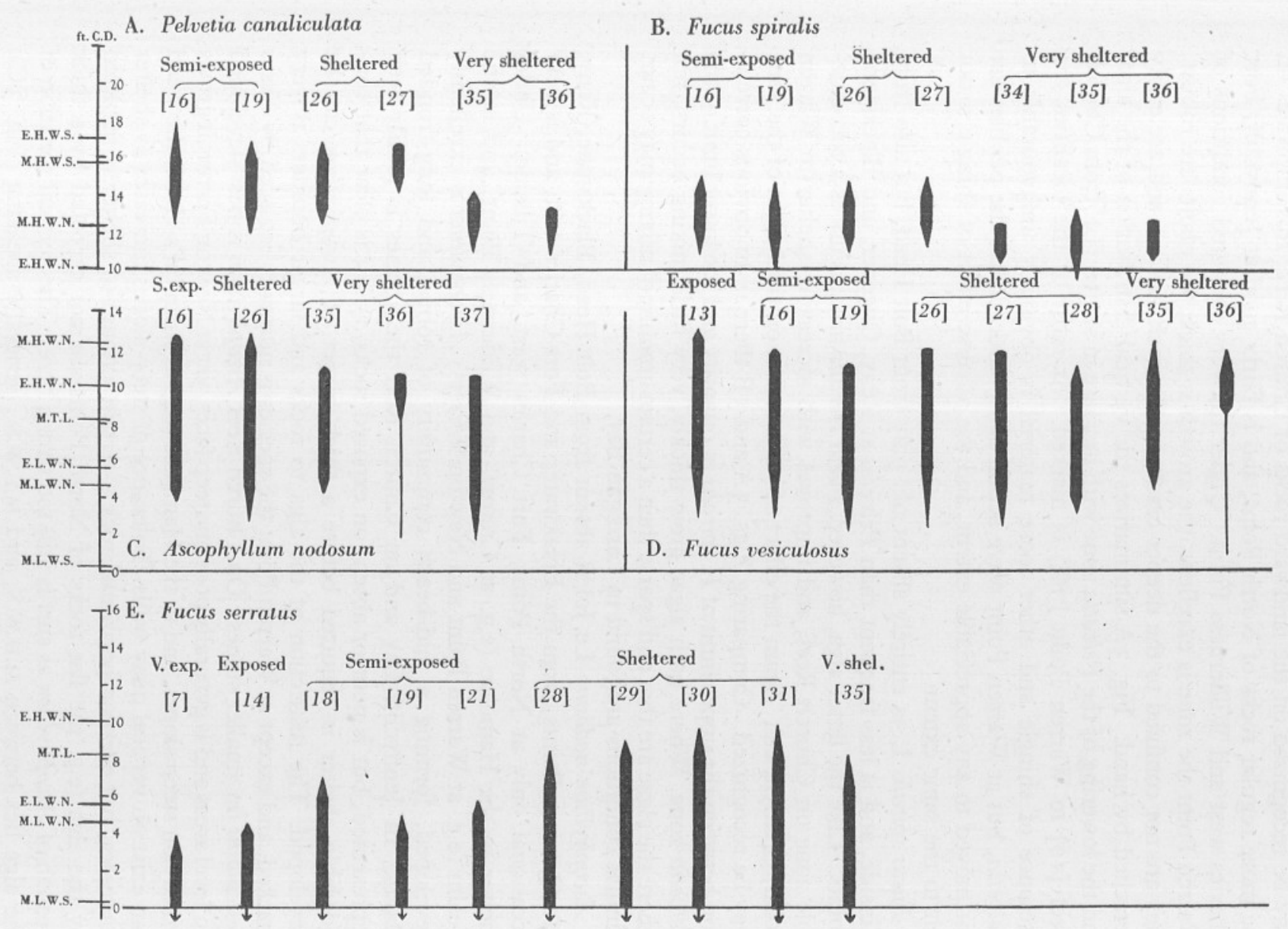

Fig. 3. Zonation of Pelvetia (A), Fucus spiralis (B), Ascophyllum (C), Fucus vesiculosus (D)

$\stackrel{+\infty}{\omega}$ and upper limit of $F$. serratus (E) at different localities. 
may be recognized on the landward rocks of Church Reef; this improves on the more regular rocks of North Point, and is fairly good at Jennycliff, Fort Charles west and Wilderness Point. Under the very sheltered conditions of Warren Point the zone is excellent, the growth is thick, the plants are robust, they are not confined to the deeper cracks in the rock surface, and are easily detached by hand. Fig. $3 \mathrm{~A}$ summarizes the vertical distribution of the alga, and the lowering of the Pelvetia zone with increase in shelter (i.e. from Church Reef [16] to Warren Point [36]) is marked. At most of the localities the presence of shingle and other loose material is obviously unfavourable to Pelvetia, but at Warren Point wave action is so reduced that the pebbles are not moved to any appreciable extent, and the adverse effect of shingle is not felt to the same extent.

Fucus spiralis L. is entirely absent not only from Bolt Head, but also from Tinside, and is less frequent than Pelvetia at Reny, Queener, and Blackstone Points. Like the latter alga, however, Fucus spiralis first occurs as a recognizable zone on Church Reef, and improves with increasing shelter to Warren Point, Cremyll, etc. Again the effect of wave action on the height of the zone may be recognized. Comparing Figs. $3 \mathrm{~A}$ and ${ }_{3} \mathrm{~B}$ there is an obvious correlation between the upper limit of $F$. spiralis in quantity and the lower limit of the Pelvetia zone. Where both algae grow thickly, very little mixing occurs, but where the algae are thin and sparse then a certain amount of mixing may occur. Similar conditions are found in Cardigan Bay.

Ascophyllum nodosum Le Jol is absent from Bolt Head, Blackstone, Reny, and Queener Points, from the Breakwater and Fort Charles east, and is very occasional only at North Point, Fort Charles west, and Tinside. Under shelter in the Hamoaze (e.g. at Cremyll and Wilderness Point) and in the Yealm (e.g. at Warren Point and Newton Ferrers) Ascophyllum is excellently developed, forming a mid-beach community of robust and long-fronded plants. In Jennycliff Bay and on Church Reef the species is locally well represented, but is poor or absent on exposed rocks, and it is clear that considerable shelter is required before a thick carpet of Ascophyllum can be developed. The restriction of the alga to rocks and larger boulders is very marked, and except at Warren Point the species is normally replaced by Fucus vesiculosus on smaller stones. On Church Reef Ascophyllum is best developed on level areas and is generally poor on steep faces, yet at Newton Ferrers it grows thickly on steep slopes, and in the Hamoaze (e.g. at Admiral's Hard) the weed can exist on vertical quay walls. Tolerance of steep slopes increases as shelter increases, but even on horizontal rock a certain amount of shelter is required by the alga (e.g. the flat rocks of North Point are not carpeted by a thick growth of Ascophyllum as surf is still too strong here). The vertical zonation of the alga lies between M.H.W.N. and M.L.W.N., generally speaking (Fig. ${ }_{3}$ C), but the upper limit is again higher under conditions of moderate wave action (e.g. Church Reef, Jennycliff Bay) than under conditions of extreme shelter 
(e.g. Newton Ferrers). There is a correlation between the upper limit of Ascophyllum and the lower limit of Fucus spiralis, especially where both zones are thick (e.g. Warren Point, Cremyll, etc.), but where the shore rock is irregular this demarcation is not nearly so obvious. The lower limit of Ascophyllum varies, but the alga appears to be capable of existing at least as low as M.L.W.S. $+2 \mathrm{ft}$., though it is generally abundant only above M.L.W.N. Gislén (I930) describes the species as extending lower in sheltered and unclean waters, possibly this explains its low lower limit in the Yealm estuary.

Fucus vesiculosus L. Though not entirely absent from any of the stations visited, this alga is extremely poorly represented at Bolt Head, Blackstone, Reny, and Queener Points, and on the south face of the Breakwater. At all these localities $F$. vesiculosus is found only as occasional and tattered plants in cracks on the exposed slopes. On Church Reef the alga is generally less well developed than Ascophyllum, but it often tends to replace the latter on the steeper slopes. At Fort Charles west and in parts of Jennycliff Bay Fucus vesiculosus may form a fairly pure (i.e. unmixed with Ascophyllum) community on the less regular stretches of rock and boulders, but at Wilderness and Warren Points it is definitely dominated by Ascophyllum. As in Cardigan Bay, Fucus vesiculosus is more tolerant of broken ground, of boulders, of steep faces, and of surf than Ascophyllum, and peaks and boulders lying in a thick carpet of the latter alga may be dominated by Fucus. The writer has suggested previously (Evans, 1947) that the general infrequency of a thick, pure community of $F$. vesiculosus may be due to the rather sharply set optimum of surf conditions necessary for this; where surf action is too strong the alga occurs merely as isolated plants and clumps, where shelter is pronounced then Ascophyllum is developed and competes successfully against Fucus for dominance. Generally $F$. vesiculosus is not found much above M.H.W.N. (Fig. 3D), but may occur above this under the influence of splash. It tends to occur to higher levels than Ascophyllum, however, which is the reverse of what has been described in Cardigan Bay. The lower limit of abundance lies generally in the region of E.L.W.N. to M.L.W.N., but where the Fucus serratus zone is well represented $F$. vesiculosus may be dominated by this alga from E.L.W.N. down. The presence of a stony lower beach at Warren Point prevents both this species and Ascophyllum from being anything more than occasional from E.H.W.N. down at this locality, but isolated plants of Fucus vesiculosus have been taken here as low as M.L.W.S. $+0.5 \mathrm{ft}$.

Fucus serratus L. As described by most workers, this species requires horizontal or gently sloping rock and a fair amount of shelter from surf, but when shelter is pronounced it may occur on steep slopes, and it may be absent even from a level beach where surf is too violent. The $F$. serratus zone is well represented on Church Reef (except on the seaward slopes of the outer reefs), at Tinside, North Point, Jennycliff, and Fort Charles west; and it achieves its maximum development at Wilderness Point, but the stony lower beach at 
Warren Point is again unfavourable. The lower limit of distribution at all localities lies below M.L.w.S., but the lowest level to which the writer has taken the species lies in the region of M.L.W.S. - I ft. (at Church Reef, Jennycliff, North Point, and the Breakwater). The absolute upper limit of distribution under optimum conditions (e.g. in the Fisher's Nose region of Tinside [3o] and at the west end of North Point [31]) is E.H.w.N., but the upper limit of abundance is variable. From Fig. ${ }_{3} \mathrm{E}$ it will be seen that the upper limit of the $F$. serratus zone is very markedly affected by the intensity of surf. At Bolt Head and Blackstone Point no distinct zone can be recognized; on the south Breakwater slope [7] the zone extends up to M.L.w.S. $+3 \mathrm{ft}$. only, but with increasing shelter at different localities this upper limit moves up the shore until, at North Point west end [31] (for example) it is as high as M.T.L. Further reduction in wave action, and in the height of wash and splash, results in a subsequent lowering of this upper limit (e.g. at Wilderness Point [35]). The ten localities figured in Fig. $3 \mathrm{E}$ are chosen from a large selection of data all showing the same general principle, i.e. that with decreasing surf F. serratus is enabled to exist higher and higher up the shore, but after a certain optimum is reached, further reduction in wave action results in a slight lowering of the upper limit.

Himanthalia lorea Lyngb. This occurs in much more wave-beaten localities than any of the other fucoids, and as Rees (1935), Gibb (1938), and others state, it is characteristic of moderately wave-beaten situations. Himanthalia is well represented at Bolt Head, Blackstone, Reny, Plymouth Breakwater, and Church Reef; at North Point it is less frequent; at Fort Charles and Wilderness Point it is occasional only. Fischer-Piette (1936) comments on the paucity of the species in bays such as Lyme Bay, and notes its abundance on projecting headlands with deep off-shore water. He suggests that this may be due to the generally heavy sedimentation of bay water, resulting in a poor penetration of light. This would explain not only the scanty development of Himanthalia at Fort Charles and Wilderness Point, but also its absence from Cardigan Bay, for the species can exist much further north than this (Kitching, 1935). Himanthalia appears to favour fairly gentle slopes (e.g. on the level stretch behind the protective blocks of the Breakwater there occurs an excellent zone of this alga). On Church Reef, characteristic fringes of Himanthalia are found at the bases of exposed $45^{\circ}$ slopes which are thickly covered with barnacles and bare of all other fucoids. Kitching (1935) agrees that the species can inhabit slopes up to $80^{\circ}$ but that it usually prefers more level ones, and it was only occasionally found on vertical landward faces and on steep gulley banks. Gibb (1938) describes a Himanthalia zone between that of Fucus serratus and the Laminarians, but in the Plymouth neighbourhood such a zone is best observed where F. serratus is poor or absent. Thus, on the south face of the Breakwater [7], Himanthalia is definitely the dominant alga up to I ft. above the Laminarian zone. On the other hand, where the Fucus serratus com- 
munity is well developed (e.g. at Jennycliff and North Point), Himanthalia mixes with this alga, and no separate belt can be distinguished. The species is common to below E.L.W.S. and its upper limit lies in the region of M.L.W.N. (see Fig. 4A), though occasional plants were taken on a north-facing, shaded slope as high as E.L.W.N. at Bolt Head [1]. The upper limit of abundance is highest on Church Reef [6] and in Jennycliff Bay [13], while under the extreme exposure of Bolt Head [1] the alga is not common above M.L.w.S. + I ft. (though it is occasional to E.L.w.N.), and the height of the Himanthalia zone, like that of Fucus serratus, appears to be limited by the degree of surf action.

A. Himanthalia lorea
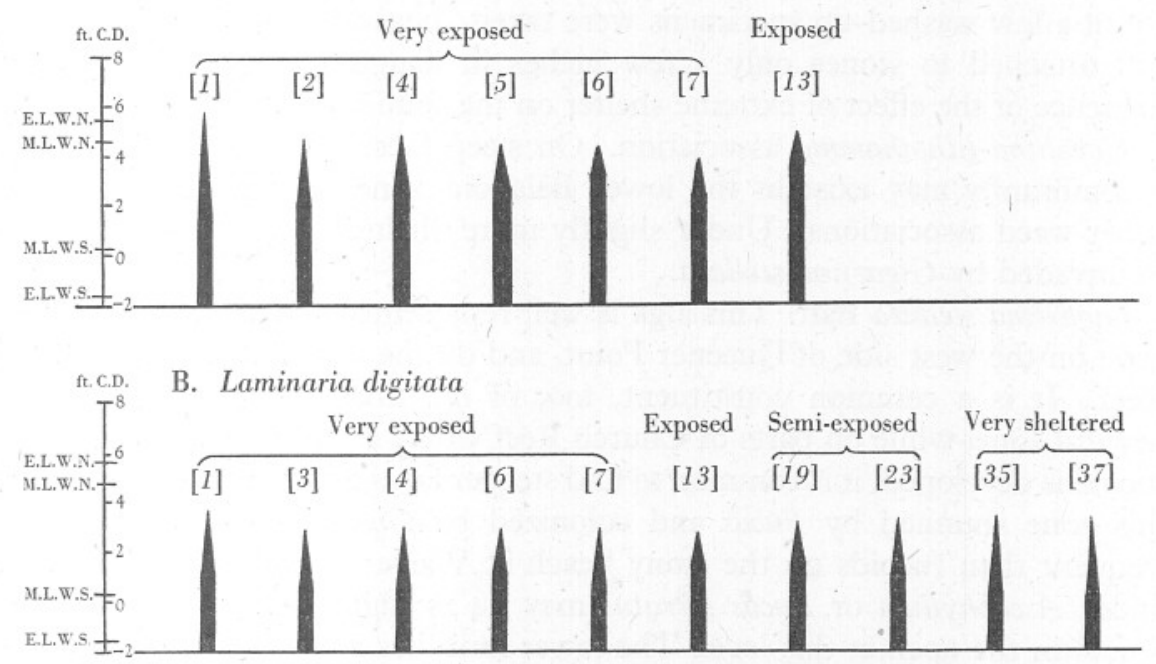

Fig. 4. Upper limits of Himanthalia lorea (A) and Laminaria digitata (B).

While adult plants are not usual above M.L.W.N., vegetative 'buttons' may be found much higher, e.g. up to M.T.L. or above on the Breakwater blocks, or even to E.H.W.N. under a thick carpet of fucoids.

Laminaria digitata Lamour. This occurs in quantity at all the stations visited, except on the stony beach of Warren Point, and is tolerant of a wide range of conditions of surf. The absolute upper limit of distribution lies just below M.L.W.N. (see Fig. 4 B), but the alga is not common (i.e. the 'Laminarian zone' does not commence) much above M.L.W.S. This zone may begin as high as M.L.W.S. $+2 \mathrm{ft}$., e.g. on the flatter rocks on the west side of Queener Point where, although surf action and wave crash are not excessive, there is generally a heavy swell and a broad wash zone. Under conditions of extreme exposure it may not extend much above M.L.W.S. $+\mathrm{I}$ ft.; on the other hand, where shelter is very pronounced L. digitata may not be common above M.L.W.S. Thus the relation between the upper limit of distribution and the intensity of surf, 
which was demonstrated for Fucus serratus and Himanthalia, holds good for Laminaria digitata also. The effect of slight shelter in allowing the alga to ascend above M.L.W.S. has been noted by Rees (1935), who states with regard to L. digitata (p. 93): 'With increasing shelter this alga is no longer confined to channels but spreads out as a belt on the top of the sublittoral, beginning on flat ledges but later, with increasing shelter, occurring as a zone above Laminaria Cloustoni. on surfaces that do not slope too steeply.'

Laminaria saccharina Lamour. As is general in Cardigan Bay and elsewhere, this species is intolerant of excessive exposure to wave action, and it is confined to pools and channels at Bolt Head, Church Reef, Reny, etc. It was never found as commonly as L. digitata at any of the stations visited. At Warren Point a few washed-up specimens were taken, measuring up to 2 yards long, but attached to stones only a few inches in diameter, which is a further evidence of the effect of extreme shelter on the stability of such a substratum.

Corallina-lithothamnia association. On steep faces at exposed points such a community may exist in the lower Balanoid zone, in the absence of all other weed associations. Under slightly more sheltered conditions this may be invaded by Gigartina stellata.

Gigartina stellata Batt. This alga is well represented in the lower Balanoid zone on the west side of Queener Point, and on the exposed reefs of Church Reef. It is a common constituent, too, of the undergrowth of the Fucus serratus zone, while on parts of Church Reef where a typical belt of the latter fucoid is developed, it is common to find steeper faces and protruding ledges in this zone shunned by Fucus and colonized by Gigartina. It is also more frequent than fucoids on the stony beach at Warren Point. Its upper limit under Ascophyllum or Fucus serratus may lie as high as E.L.w.N., but little occurs in the open at this level. The lower limit lies beyond E.L.W.S.

Laurencia pinnatifida Lamour. Like Gigartina and Corallina, this is often common in the undergrowth of a zone of Fucus serratus, but also occurs on rocks too exposed for fucoid growth. It is common in patches on rocks thickly encrusted with barnacles, and such Laurencia-Balanus communities normally occur above a lower zone of Gigartina and barnacles. The upper limit of Laurencia at Queener Point lies above M.T.L., but at Bolt Head the alga is restricted to lower levels. It is generally patchily distributed, and does not seem to form a 'continual carpet' such as Rees (1935) describes at Lough Ine.

Porphyra umbilicalis (L.) J.G. Ag. is extremely haphazard in its distribution, occurring from conditions of extreme exposure to those of extreme shelter, and is apparently unaffected by either. Steep, barnacle-encrusted reefs, and smooth boulders are equally well colonized by Porphyra, and it is also commonly epiphytic on fucoid algae. Cotton (I9I2) remarks with regard to the Porphyra association: 'Doubtless surf and spray are largely responsible... this does not account for all the differences that have been noted.' Though the alga occurs sporadically from the Laminarian zone to above E.H.w.S. on exposed 
peaks, it often tends to form well-defined bands of growth on such peaks and slopes. Thus on steep faces at Bolt Head a band was noted in the M.H.W.S.E.H.W.S. region; on the south face of the Breakwater two such bands were observed, one between M.H.W.N. and M.H.W.S., the other at about M.L.W.N., with practically no Porphyra in between. The reason for this is not clear.

Lichina pygmaea Ag. The distribution of this lichen in the Plymouth area has been described by Naylor (I930), and the present survey confirms the major part of her observations. L. pygmaea is best developed on steep exposed slopes, with rough or barnacle-encrusted surfaces (e.g. at Bolt Head, Blackstone, Reny, etc.). Yet, provided water movement is strong enough, the lichen is not restricted to vertical faces, but occurs quite thickly on gentle slopes (e.g. at North Point). It was not taken under the sheltered conditions

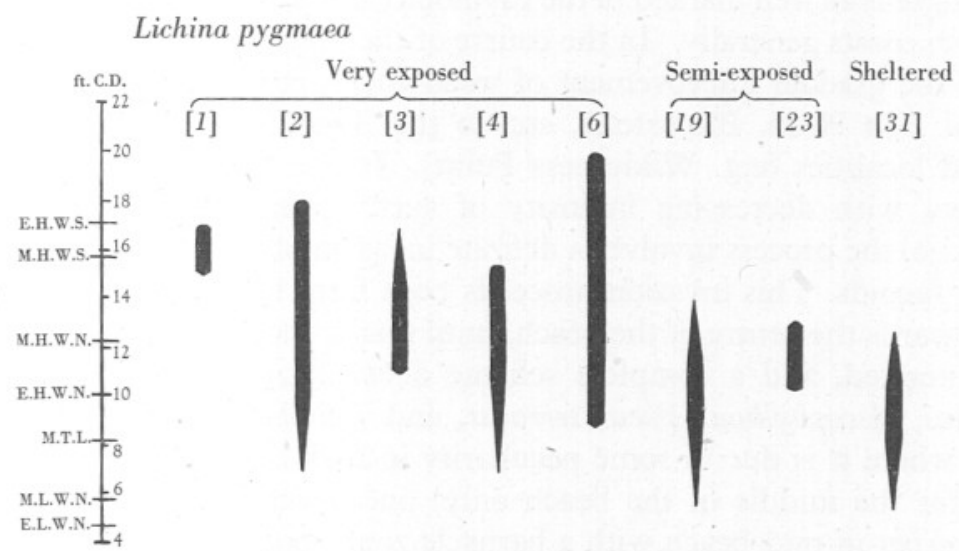

Fig. 5. Zonation of Lichina pygmaea.

of Warren and Wilderness Points, nor, as Naylor (I930) describes, is it present in Jennycliff Bay. The lichen is normally thickest and most extensive on slopes facing in a southerly direction, but it is commonly well developed even on rough landward faces where these are covered with barnacles; it also occurs in caves and overhangs when these are exposed to strong water movement, and the restriction of L. pygmaea to brightly illuminated surfaces as Naylor (I930) remarks is not at all marked. Similar results have been obtained in Cardigan Bay, and the writer is inclined to believe, despite the absence of the lichen from the shaded shore of Jennycliff Bay, that L. pygmaea is primarily dependent on surf action and rough rock, and that no simple light effect can be distinguished.

Naylor (1930) states that the lichen never extends above the Pelvetia zone, and generally achieves its lower limit around M.T.L. Only occasionally in the present survey was it taken as low as M.L.W.N., and its lower limit (see Fig. 5) is variable, with no clear relation to surf or any other factor. Where Lichina and 
Pelvetia are both present (e.g. on the landward rocks of Church Reef, at North Point, and at Fort Charles) the lichen always occurs below the alga (compare Figs. 3A, 5), but with increasing exposure to waves the Pelvetia zone disappears and the upper limit of Lichina rises until (e.g. on the seaward peaks of Church Reef) it extends to above E.H.w.s. At semi-exposed localities the upper limit lies in the M.H.w.N.-M.H.W.S. region: The high upper limit of the lichen on the seaward reefs of Church Reef [6] is worth noting: though not quite so exposed to surf as Bolt Head, for example, the low position of these reefs on the shore results in them receiving splash and spray even at low water on rough days.

\section{Discussion on the Distribution of Algae}

The correlation between the intensity of wave action and the distribution of littoral algae is as well marked in the Plymouth area as it is in Cardigan Bay and on British coasts generally. In the course of the present survey it was possible to trace the gradual improvement of weed cover, from the typical 'barnacle areas' of Bolt Head, Blackstone, etc. to the 'fucoid areas' characteristic of sheltered localities (e.g. Wilderness Point). It is a significant fact that this transition, with decreasing intensity of surf, appears to follow a definite pattern, i.e. the process involves a definite invasion of the mid-beach Balanoid zone by fucoids. This invasion proceeds both from low water and from high water towards the centre of the beach, until finally the barnacle belt is more or less obliterated, and a complete scheme of weed zonation (Pelvetia, Fucus vesiculosus, Ascophyllum, Fucus serratus, and Laminaria) is achieved. Thus (except where it is due to some peculiarity in rock configuration resulting in shelter for the middle of the beach only) one never finds a well-developed fucoid carpet in mid-beach with a barnacle zone above and below it. On the other hand, a mid-beach Balanoid zone passing into fucoids above and below is quite general in semi-exposed situations. Thus at Bolt Head and Blackstone Point, the entire beach from M.L.w.s. upward is occupied by Balanus and Chthamalus, merging into a zone of Littorina rudis and L. neritoides at highwater mark, and in such areas there are no intertidal fucoid communities whatsoever. Under slightly more sheltered conditions (e.g. on the west side of Queener Point), not only does the Laminaria digitata belt creep up from M.L.W.S. but also Corallina, Gigartina and Laurencia tend to invade the lower part of the Balanoid zone. The next stage is the appearance of a belt of Himanthalia above the Laminarian zone, when surf action decreases to the extent it does on the Breakwater and on the seaward parts of Church Reef. Still more sheltered conditions lead to the appearance of Fucus serratus as a zone at low water, and the upward extension of this zone, as the intensity of surf decreases, has already been demonstrated (Fig. ${ }_{3} \mathrm{E}$ ). Under slightly less sheltered conditions than those required by $F$. serratus, first Pelvetia and then Fucus spiralis make their appearance at the top of the shore, and the down- 
ward extension of the zones of these algae has also been noted (Figs. 3 A, B). This is the typical state found in semi-exposed localities, and may be summarized thus: Littorina zone, Pelvetia, Fucus spiralis, barnacles (with scattered plants of $F$. vesiculosus), $F$. serratus, Laminarians. $F$. vesiculosus has been present from an early stage in the transition, but as occasional and tattered plants only; now, as shelter improves, the alga becomes more frequent and the individuals more robust. Still further reduction in the intensity of surf allows Ascophyllum to appear; this soon becomes dominant, and where surf is reduced to a minimum (e.g. at Wilderness Point, Newton Ferrers, etc.) the Ascophyllum community occupies the mid-beach to the complete exclusion of the Balanoid zone.

Such a process cannot, however, be ascribed to the decreasing energy of surf action alone; were this so, one would expect to find the Fucus vesiculosus zone the first to appear, since individual plants of this alga are apparently extremely tolerant of surf. The writer would suggest that not only is the actual force of wave shock important with respect to the algae, but that the relative frequencies with which different shore levels are subjected to wave shock must also be taken into consideration. Stephenson (I94I) mentions a suggestion made by D. P. Wilson that the frequency and duration of wave action may determine the upper limits of distribution of low-tide algae, and this certainly appears to be true for Fucus serratus, Laminaria digitata, etc. (see Figs. $3 \mathrm{E},{ }_{4} \mathrm{~B}$ ). At the level of M.L.W.S. the shore is comparatively seldom exposed to breaking waves, for during most tides such levels remain submerged; similarly M.H.W.S. and levels above this are only relatively occasionally reached by surf. At M.T.L., however, direct wave shock is experienced twice during every complete tide, and the same is true at all levels between E.L.W.N. and E.H.W.N. From both these levels, proceeding towards low water and high water respectively, there is a progessive decrease in this frequency factor. Both $(a)$ the actual force of wave shock, and $(b)$ the frequency of this effect will act adversely on the fucoids, and it is reasonable to suggest that the reduction in one of these will mitigate, to some extent, the combined adverse effect of both. Thus, reduction in the factor of intensity of wave force enables Fucus serratus (for example) to withstand the frequency factor to a greater degree, and so to exist higher up the shore. (The frequency remains comparatively unaltered, though the intensity of surf will also tend to determine the width of the zone affected by the breaking waves to some extent.) For Pelvetia and Fucus spiralis at the top of the shore the same argument applies, though since such algae are more limited in their potential depth of zonation than $F$. serratus, the downward extension of these algae with increasing shelter is not so marked as the upward extension of $F$. serratus. Still further reduction in the intensity factor results in still greater tolerance of the frequency factor, and in still further extension of such algae towards mid-beach. Finally the actual force of wave shock becomes so much reduced (e.g. at Wilderness Point) that the frequency with 
which different shore levels are subjected to breaking waves has little effect, and the entire beach is favourable to fucoid growth.

The presence of weed-free zones in mid-beach has been noted by various workers, and attributed to different causes. Grubb (1936) describes a 'bare zone' between the $F$. spiralis and the Laurencia-Corallina associations at Peveril Point, Dorset, and suggests two possible causes. She points out that in this region of the beach (M.H.W.N. to M.L.W.N.) there occurs the maximum fluctuation in periods of submergence and emergence, and that any alga colonizing such levels would need a very adaptable physiology. Secondly, Grubb (1936) remarks that the 'bare zone' is covered or uncovered during the third and fourth hours of tidal flow or ebb, when the rate of water movement is greatest, and that (p. 409), 'this comparatively rapid movement may have something to do with the absence of vegetation here'. Yet the same worker also states (p. 409) that: 'In the sheltered places at Peveril Point...Fucus serratus may grow in this region, but for the most part the rocks are too exposed for this species, or for Ascophyllum, and since no other species has taken their place, they remain bare.' The presence of Fucus serratus in the 'bare zone' at Peveril Point when shelter is experienced is significant, and it appears that this is only another example of what has already been described. Indications of the same phenomenon were noted in Cardigan Bay, but in this locality the range in conditions of exposure and shelter is not wide enough to enable one to describe the process of algal invasion of the mid-beach with the clarity with which it can be seen on the more irregular coastline studied in the present survey. To summarize then, both the actual intensity of wave shock and the frequency of this factor must be taken into account when considering surf effects.

Various opinions have been expressed with regard to the relative tolerance to surf exhibited by the fucoids, especially by Ascophyllum and Fucus vesiculosus. Both Børgesen (I908) and Zaneveld (1937) appear to hold that the former alga can withstand greater intensity of water movement, but most workers (e.g. Cotton, 1912; Kitching, 1935, and others) take the opposite view. Both David (194I) and the present writer have found F. vesiculosus to be the least affected by surf in Cardigan Bay. Cotton (I9I2) arranges the algae in the following order of decreasing tolerance: $F$. spiralis, $F$. vesiculosus, Pelvetia, Ascophyllum. Gislén (1930) gives the series as: Fucus vesiculosus, F. serratus, F. spiralis, Ascophyllum; while Kitching (1935) gives: Fucus vesiculosus, Pelvetia, Fucus spiralis, Ascophyllum. From observations in the Plymouth locality the writer would arrange the algae studied in the following order: 'lithothamnia', Porphyra umbilicalis, Corallina, Fucus vesiculosus, Himanthalia, Laminaria digitata, Laurencia pinnatifida, Gigartina stellata, Pelvetia, Fucus spiralis, F. serratus, Ascophyllum. This series demands some comment, in view of what has just been said with regard to wave shock and wave frequency. (I) Fucus vesiculosus not only exists under conditions of extreme surf intensity, but also at levels where the frequency of waves is at a maximum, and this 
species must be considered as exceptionally tolerant of the adverse effects of surf. It exists, even, on slopes too exposed for the appearance of Himanthalia, Laminaria, Laurencia or Gigartina above M.L.w.S. (2) The apparent intolerance of Ascophyllum may be largely due to its position in mid-beach. This would explain a phenomenon previously commented on in the Cardigan Bay investigation, i.e. the presence of solitary and very battered plants of this alga on lowlevel reefs. Yet it is obviously less tolerant than any of the other fucoids to the factor of wave shock alone, even allowing for the frequency factor. (3) Pelvetia exists in a few localities where Fucus spiralis is absent, and though its zone is slightly further from the zone of maximum wave frequency (i.e. E.H.W.N. to E.L.W.N.) than that of the latter alga the difference in frequency cannot be very great, therefore Pelvetia appears to be the more tolerant of the two species. (4) Both Fucus spiralis and Pelvetia are more frequent in local shelter at exposed points than is Fucus serratus, which therefore appears to be the least tolerant of these three. Here, however, a further complication is introduced. While Pelvetia and Fucus spiralis spend most of their time above water level, $F$. serratus (and low-level algae in general) is, for the greater part of the time, submerged, and though actual wave crash may not be experienced during the whole of the time of submergence, the effects of back-wash, currents, tidal drag, and swell are likely to be important. (5) Laminaria digitata occupies levels which are not often exposed to breaking waves, and it may be argued that its apparent high degree of tolerance of wave shock is due to its low zonation, and that actually it is no less susceptible to this factor than is Fucus serratus. But the sharp demarcation between a profuse Laminarian zone and a zone bare of $F$. serratus, which may be observed at many exposed points, does not favour this suggestion, for the factor of wave frequency is not likely to change so sharply within such a narrow vertical range to account for this. Furthermore, the strong holdfast, the leathery and much-divided fronds, and the supple stipe of Laminaria digitata would seem to indicate that this species has a very high degree of tolerance of surf. (6) The same is true of Himanthalia but, judging from its rather more frequent appearance than Laminaria above M.L.W.S., it would appear to be slightly more tolerant than the latter. (7) The ability with which species like lithothamnia, Corallina, Porphyra, Gigartina and Laurencia appear above M.L.W.S. under conditions of extreme exposure indicates that these are extremely tolerant both of the actual force of wave shock and of the frequency of this factor.

\section{Fauna}

Barnacles. Three species of Cirripedes are considered, Balanus perforatus Brug., Balanus balanoides (L.), and Chthamalus stellatus (Poli). The last two thrive best at exposed points, and constitute the 'Balanoid zone' characteristic of such localities; Balanus perforatus is commonly found under rather more sheltered conditions and will be considered later. 
Fischer-Piette (1933) and Moore \& Kitching (1939) describe the distributions of Balanus balanoides and Chthamalus stellatus along British coasts; and it appears that Plymouth lies in an intermediate position on the south coast. Further west, towards Cornwall, Balanus dies out until Chthamalus only is left; further east, towards the Isle of Wight, it is Balanus which becomes increasingly dominant, and Chthamalus eventually disappears. In the Plymouth neighbourhood, however, both species occur freely, Chthamalus being dominant on the upper beach and Balanus on the lower beach. The effect of surf on the state of development of the Balanoid zone, and the negative correlation with fucoids have already been considered in this paper; various other general features are discussed in the work on Cardigan Bay, and here it is necessary only to consider the features of vertical distribution of the two species.

The upper limit of barnacles in quantity, or the 'Chthamalus-line', usually best marked on steep exposed surfaces, varies in height in relation to the intensity of surf experienced (see Fig. 6A), and so does the absolute upper limit of Chthamalus. The outer reefs of Church Reef are thickly encrusted with this barnacle to above E.H.W.S., which is a reflexion not only of the exposure to strong surf but also of the low position of these reefs on the shore: they receive splash on a rough day even from low tides. Elsewhere the upper limit of barnacles in quantity varies from just above M.H.W.s. (at Bolt Head [1], etc.) to just above M.H.w.N. (e.g. on sheltered north faces at Jennycliff [24]). When shelter increases still further no distinct line can be recognized, and barnacles are reduced over the whole beach.

The lower limit of the barnacle belt, too, is frequently marked as a line on exposed vertical faces, i.e. the 'Balanus-line'. In general this is less well marked than the Chthamalus-line, and is distinct only on steep faces at lowtide levels, but in places (e.g. at North Point), even when the rocks are horizontal, it is possible to recognize a fairly definite limit, below which barnacles in quantity die out. It is difficult to choose definite localities at which both the Chthamalus- and Balanus-lines are clearly recognizable, and at which the intensity of exposure is approximately equivalent at the top and the bottom of the shore, but an attempt is made to do this in Fig. 6A. It will be seen that, with increasing shelter, the lower limit of the Balanoid zone rises from M.L.w.S. to the region of M.L.W.N.; Fig. 6B gives a more comprehensive picture of this process. The same feature has been described in the Isle of Man by Moore (I935a). At many localities (e.g. North Point) it would appear that this raising of the lower level of the Balanoid zone is caused by the upward extension of the lower-shore fucoid belt, and this may be partially true. However, surf in itself also seems to have a more direct effect on the lower limit of barnacles in quantity. It is common to find protruding rocks near low-water level with a well-marked Balanus-line on their seaward face just above M.L.w.S., and with nothing below this line but a thin sheet of calcareous algae; obviously here 
A. Balanus balanoides and Chthamalus stellatus

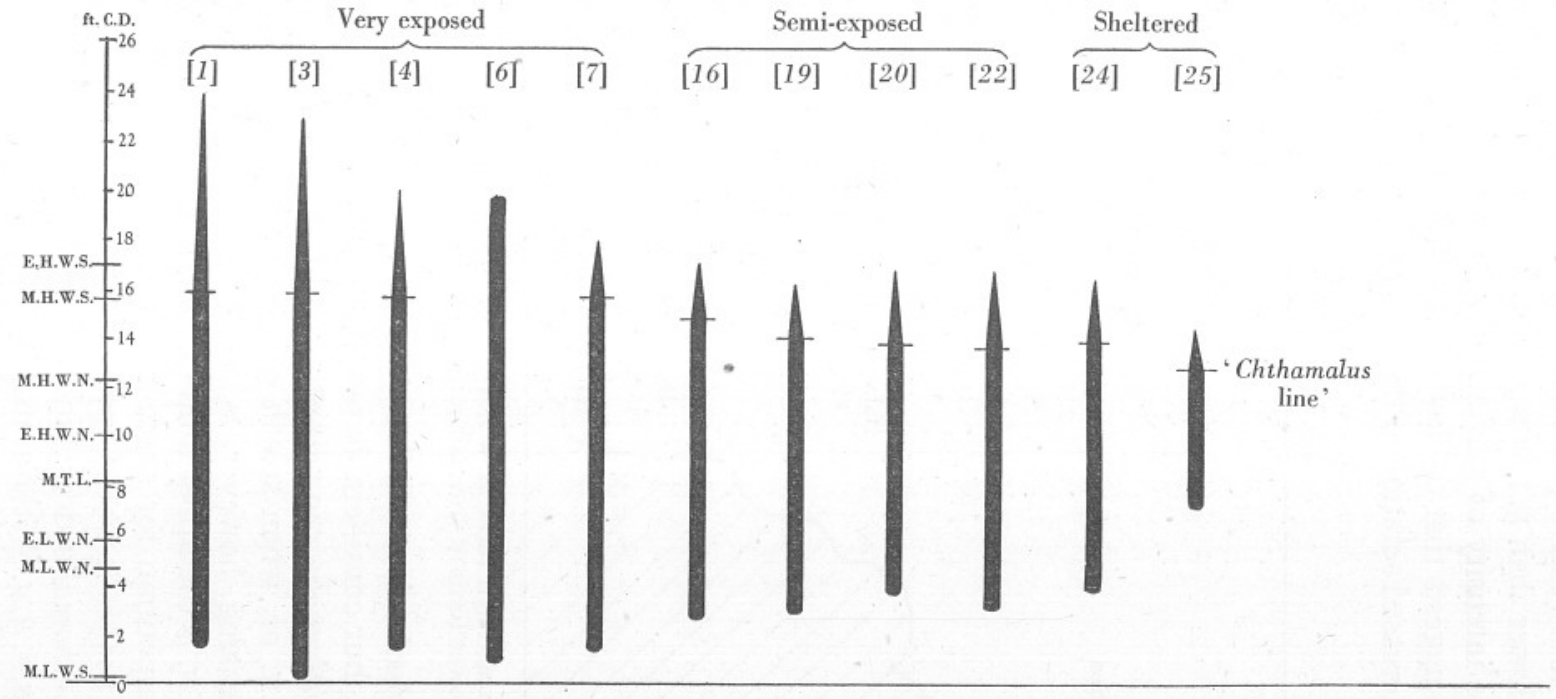

B. Balanus balanoides (lower limit)

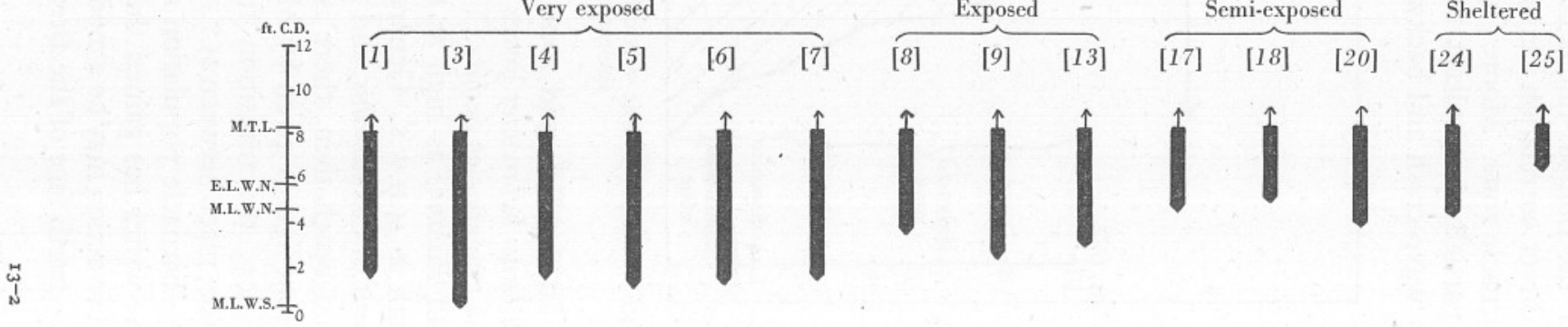

Fig. 6. Zonation of barnacles. (A) The vertical width of the Balanoid zone at different localities;

(B) The lower limit of the Balanoid zone under different degrees of exposure to wave action. 
fucoids are not limiting for the lower limit of Balanus. Moreover, on a similar vertical face to landward of the first (Fig. 7), there may be no fucoids again, but the Balanus-line is now no lower than M.L.W.N.; thus there appears to be a direct correlation between the intensity of surf and the lower limit of the barnacle zone. Moore (1935a) suggests that the lowering of this limit by surf is partially due, at least, to the increased aeration of the water to greater depths, by wave-crash and backwash.

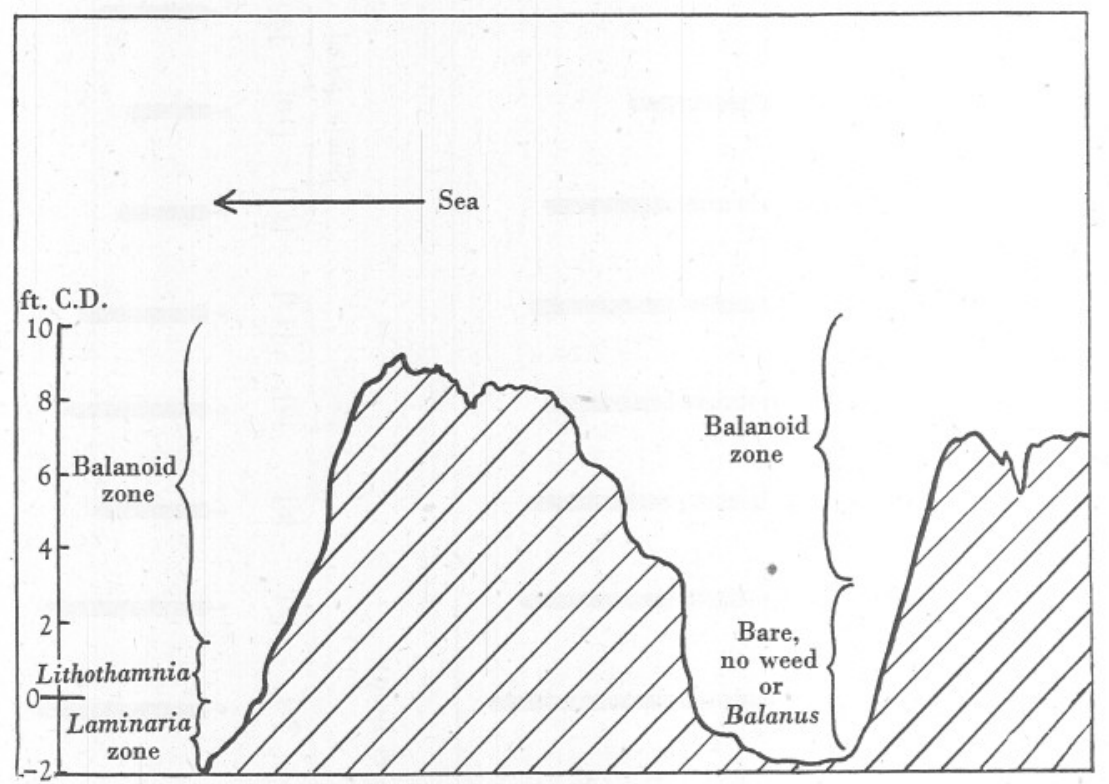

Fig. 7. Diagrammatic vertical section through reefs in Wembury Bay to show the effect of shelter on the lower limit of the Balanoid zone.

In the Balanoid zone Chthamalus is dominant on the upper shore, and Balanus balanoides lower down, but considerable overlapping of the zones of the two species occurs. Thus Chthamalus can persist as low as M.L.W.S. $+2 \mathrm{ft}$., and Balanus as high as M.H.W.N. or, when splash effects are introduced, as high as M.H.W.s. Generally speaking, however, M.L.W.N. is about the lower limit of Chthamalus, and M.H.w.N. is the upper limit of Balanus balanoides. In mid-beach then, there is a competition for space between the two species. From figures given by Moore (I935b) it would appear that, in the Plymouth region, the transition from Chthamalus-dominance to Balanus-dominance takes place between M.T.L. and E.H.W.N. Without making a detailed analysis of the barnacle population at different points it is impossible to be certain, but the writer has gained the impression during this survey that the intensity of wave action may be a modifying factor in this respect. In Jennycliff Bay and on the north face of the Breakwater the transition occurs in the region of M.T.L., 
but on steep, exposed slopes at Bolt Head and Blackstone Point Chthamalus may be dominant as low as E.L.W.N.

Summarizing, then, intense wave action tends (a) to raise the upper limit of the Balanoid zone; $(b)$ to lower the lower limit of the Balanoid zone; (c) possibly to lower the level at which the transition from Chthamalusdominance to Balanus-dominance occurs.

Balanus perforatus Bruguière. Unlike the other two barnacles studied, this species is not overfond of strong surf, yet it favours a certain amount of water movement. Fischer-Piette (I936) has noted its scanty development on projecting headlands such as Start Point, and its improvement at wave-beaten positions in bays. It is obvious from the present survey, too, that $B$. perforatus is characteristic of semi-exposed situations; thus it was not found at Bolt Head or Blackstone, and is only occasional under extreme conditions of shelter (e.g. at Wilderness Point). In moderately exposed localities (e.g. Jennycliff Bay, Church Reef, North Point) the species is common in cracks, fissures, overhangs, etc., where surf is not too strong, and in such positions it may be the dominant barnacle over a small area of rock surface. On the flatter rocks on the west side of Queener Point, and on parts of the West Hoe rocks B. perforatus is very well represented and commonly associated with patches of Mytilus edulis. Mussels do not always occur where the barnacle is profuse, however, and the association, though frequent, is probably purely coincidental, as Fischer-Piette (I936) suggests.

Balanus perforatus extends to below M.L.w.s. in quantity, and its upper limit lies in the region of E.H.W.N.; though on north-facing overhangs on the outer reefs of Church Reef this may be raised by splash as high as M.H.W.N.

Littorina neritoides (L.). In the Plymouth locality, as in Cardigan Bay, this species is best represented on steep, rough, and very exposed surfaces, and is especially abundant at Bolt Head, Blackstone, and Queener Points. In semiexposed localities (e.g. Jennycliff, Church Reef landward rocks, etc.), it is reduced in numbers; at North Point it is comparatively infrequent on the horizontal rocks; at Wilderness Point only very occasional specimens were found; while at Warren Point it was not taken at all. This agrees with the results of Lysaght (I94I), who finds that L. neritoides is favoured by a barnaclecovered substratum but disfavoured by excessive development of weed. Both Lysaght (I94I) and Colman (I933) discuss the tropic reactions of this snail, and Colman concludes that its restriction to cracks and crevices above high water is prompted by its need for shelter from wave shock. Yet, at Queener Point for example, it is common to find literally hundreds of individuals congregated on steep exposed surfaces in mid-beach, where the intensity and frequency of surf action are both high. It is probable that the adhesive powers of the snail are considerably stronger when it is wet than when it dries out, for $L$. neritoides above M.H.W.S. level can be easily blown off the rock. 
A. Littorina neritoides

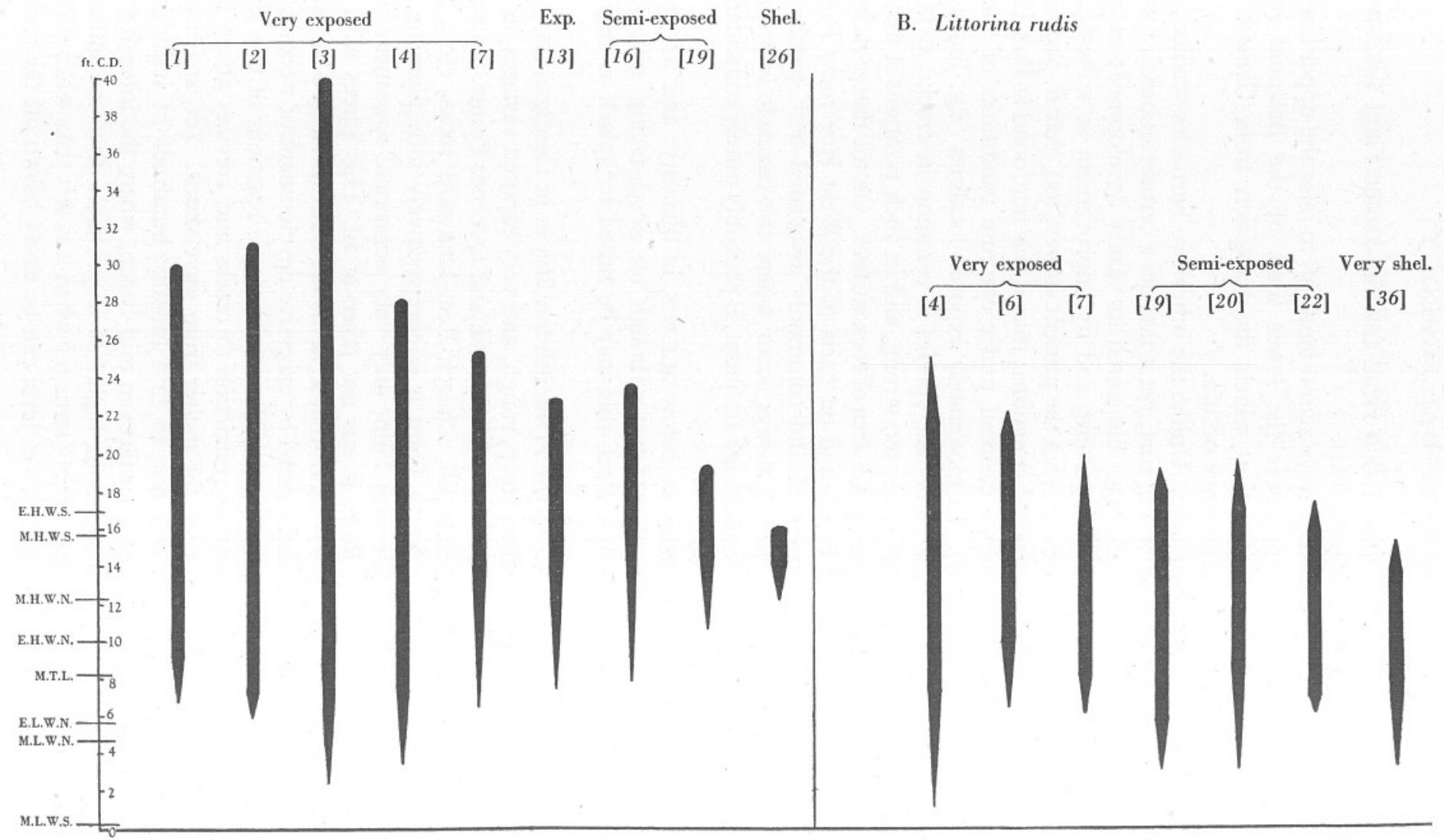

Fig. 8. Zonation of Littorina neritoides (A) and L. rudis (B). 
The species is usually described as inhabiting levels above high-water mark, and, while it is admittedly most characteristic of such levels, occasional specimens were taken in Cardigan Bay as low as M.L.W.N. Lysaght (I94I) records it to below M.T.L. on the Plymouth Breakwater, and reports the finding of mature snails on piles permanently submerged for at least a year. This being so, it is likely that Colman's (I933) lower limit, which he confesses is 'somewhat uncertain', is considerably too high. During the course of the present survey the species was definitely taken to below M.T.L. even on the landward portion of Church Reef, while at Blackstone Point it was found occasionally down to M.L.W.S. $+2 \mathrm{ft}$. (Fig. 8A). Although it was found to M.L.W.N. in Cardigan Bay, L. neritoides is never common much below M.H.W.S. in the region; in the Plymouth region, however, the writer has found dense congregations of the species in the M.T.L.-E.L.W.N. region (e.g. at Bolt Head, Reny, Blackstone, and Queener Points). Such groups are inevitably restricted to steep, rough faces, with a thick barnacle cover; on neighbouring flatter surfaces at the same shore level $L$. neritoides may be very occasional only. From Fig. $8 \mathrm{~A}$ it can be seen that the intensity of surf raises the upper limit of distribution, and lowers the lower limit.

Littorina rudis (Maton). This species favours less exposed situations than L. neritoides, and is generally inferior to it in numbers at places such as Bolt Head, Blackstone, and Reny Rocks. On barnacle-covered slopes, L. rudis is largely confined to the shelter of empty barnacle shells. At North Point, Jennycliff Bay, Wilderness Point, and other semi-exposed or sheltered localities the species is more frequent than L. neritoides, occurring in large numbers among the sparse zones of Pelvetia and Fucus spiralis and at heights above these; but at Warren Point it is most abundant on shingle and boulders, and does not appear to favour the thick weed cover met with here. Littorina rudis is fond of somewhat irregular and broken rock, with plenty of pools, cracks, crevices, etc., while boulder areas (e.g. at Sandhill Point in the Salcombe Estuary) are usually well colonized by the snail. Vertical surfaces, unless deeply fissured and not exposed to excessive wave action, are not generally as popular as more level rock.

The upper limit (Fig. 8B) is lower than that of L. neritoides but may be raised by splash. The species is usually not very common much below M.T.L., and the intensity of surf does not appear to have any marked modifying effect on the lower limit of distribution. On the Breakwater, L. rudis was not taken below E.L.W.N., but on Queener Point specimens were found as low as M.L.W.S. + I ft.; Moore (I940) also describes the lower limit of this species as variable.

Littorina littorea (L.). This is even less tolerant of surf than L. rudis, and no specimens were recorded at Bolt Head, Reny, Blackstone, or the Breakwater, while at Queener Point it is occasional only in sheltered gulleys. At North Point, and in Jennycliff and Wembury Bays it occurs very commonly on level broken ground where weed is not too profuse. In the Yealm estuary L. littorea 
is abundant on the stony beach in the neighbourhood of Warren Point, and may be the dominant animal species on such a substratum. Its habit of congregating on boulders, on isolated weed clumps, in shallow pools, etc., is well marked, and leads to a somewhat local distribution. Curiously, L. littorea was not found, even in local shelter or on suitable ground, in the Tinside-West Hoe region, and was only occasionally recorded at Wilderness Point, both of which are limestone areas.

The upper limit of distribution (Fig. 9A) is variable, and appears to be raised by splash. The lower limit is not well defined either; the snail generally occurs lower on stones (e.g. at Warren Point) and in gulleys than it does

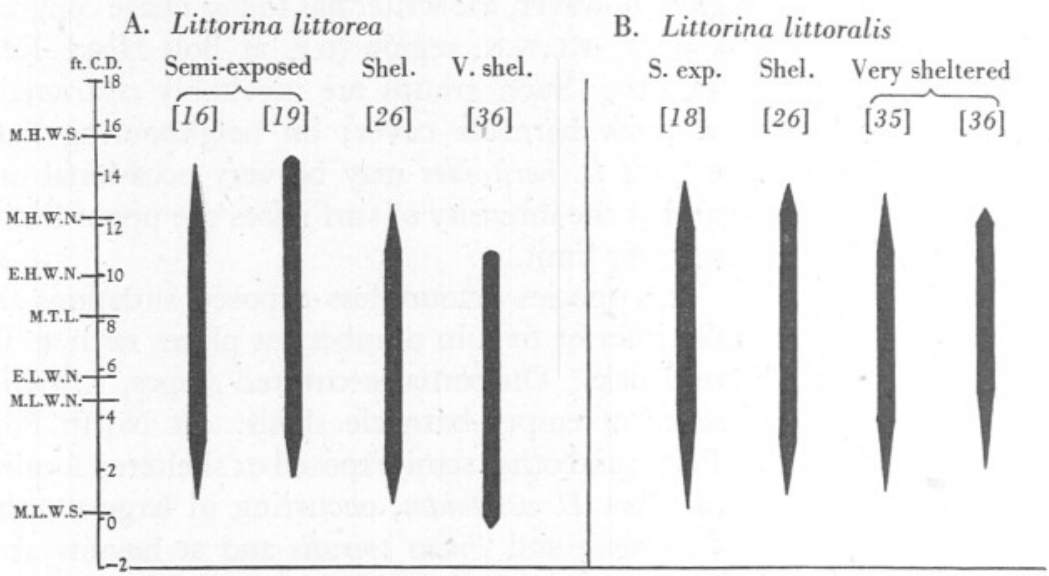

Fig. 9. Zonation of Littorina littorea (A) and L. littoralis (B).

when the lower shore is densely covered by fucoids. It is most abundant above M.L.W.S. $+2 \mathrm{ft}$., but at Warren Point [36] it is common as low as M.L.W.S. $-0.5 \mathrm{ft}$.

Littorina littoralis (L.). As usual, L. littoralis is confined to fucoid areas, and was found to be most abundant in weed zones at Church Reef, Wilderness Point, Warren Point, and Jennycliff. Yet at Fort Charles west, where the Fucus vesiculosus belt is good, Littorina littoralis is surprisingly poorly represented. In its vertical distribution, too, $L$. littoralis is influenced by the distribution of fucoids. Thus the scarcity of weed on the stony lower beach at Warren Point (Fig. 9B [36]) results in the occasional presence of the snail. Generally speaking the zone of abundance of $L$. littorea lies between M.H.w.N. and M.L.W.N. (Fig. 9B), but occasional specimens have been taken as high as M.H.W.N. + I ft. and as low as M.L.W.S. In moderately exposed and sheltered localities (e.g. Jennycliff Bay and Warren Point) L. littoralis occupies a somewhat higher zone on the beach than L. littorea. 
Osilinus lineatus (da Costa). Osilinus is intolerant of excessive exposure to surf, and was not found at Bolt Head, Blackstone, on the south face of the Breakwater, or on the outer reefs of Church Reef. At Queener Point the species is entirely confined to the shelter of gulleys and channels. It was not taken at Tinside, and only a single specimen was discovered, after prolonged search, at Wilderness Point; Moore (1940) also records its absence from Rum Bay, which is another limestone area, yet on the Staddon Grits of Jennycliff Bay, a short distance away, Osilinus is quite common. The favourite habitat of the species is the same as it is in Cardigan Bay, i.e. fairly sheltered level rock, or areas of boulders and shingle, especially when these occur in gulleys. On such ground the snail is common in Jennycliff Bay, and very frequent along the shore of Wembury Bay to Church Reef. On Church Reef, it is local in distribution on the landward portion, but is not as restricted in its horizontal distribution as Colman (1933) describes. At Warren Point, though Osilinus does occur under weed, it is much more abundant on shingle areas, and an 'Osilinus zone' may be recognized at the top of the stony beach here, as in many places in Cardigan Bay. On steep faces, when these are very sheltered, the snail is occasional, but it was never found on overhanging surfaces.

Colman (1933) describes a very narrow vertical range for Osilinus, between M.H.W.N. and E.H.W.N. In Cardigan Bay the species has been found to occupy a much wider range, from above M.H.W.N. to M.L.W.N., while Moore (I940) has described a similar range at Wembury. Fig. IOB shows that its general zonation lies between high and low water neaps at the four localities at which it occurs in numbers. It would appear that here, again, splash is effective in extending the upper limit. The low lower limit at Warren Point [36] may be due to the stony lower beach, which is an ideal habitat for Osilinus. Above E.H.W.N. the snail is frequent on open rock surfaces, below this level it is confined to gulleys, though not necessarily to gulleys with a fresh-water influence as Walton (19I5) suggests. Possibly this restriction of the species to gulleys at levels below E.H.W.N. may be due to the frequency of wave shock at such levels.

Gibbula umbilicalis (da Costa). At Bolt Head, Blackstone and Reny, G. umbilicalis is confined to pools and crevices; and while it is intolerant of excessive surf action, it is rather more tolerant of this factor than Osilinus or Littorina littorea. However, it favours similar ground to the last two species, i.e. flat, fairly sheltered rocks, boulders and stones, etc., though it is more commonly associated with fucoids than is Osilinus. Lithothamnia-encrusted pools often contain a few Gibbula umbilicalis, and on exposed points the species may be entirely restricted to such pools. This species, again, is poor on the limestone of Wilderness Point, and very occasional from Tinside to West Hoe. Yet it is fairly common on the limestone blocks of the Breakwater and in the holes and cracks between these blocks.

G. umbilicalis is slightly lower in its vertical distribution than Osilinus (see Fig. IoC); its upper limit lies generally between E.H.W.N. and M.H.W.N., but 
may be raised by splash. In the M.L.W.N.-M.L.W.S. region the species tends to die out in numbers, but it may often be found as low as M.L.W.S., or slightly lower than this.
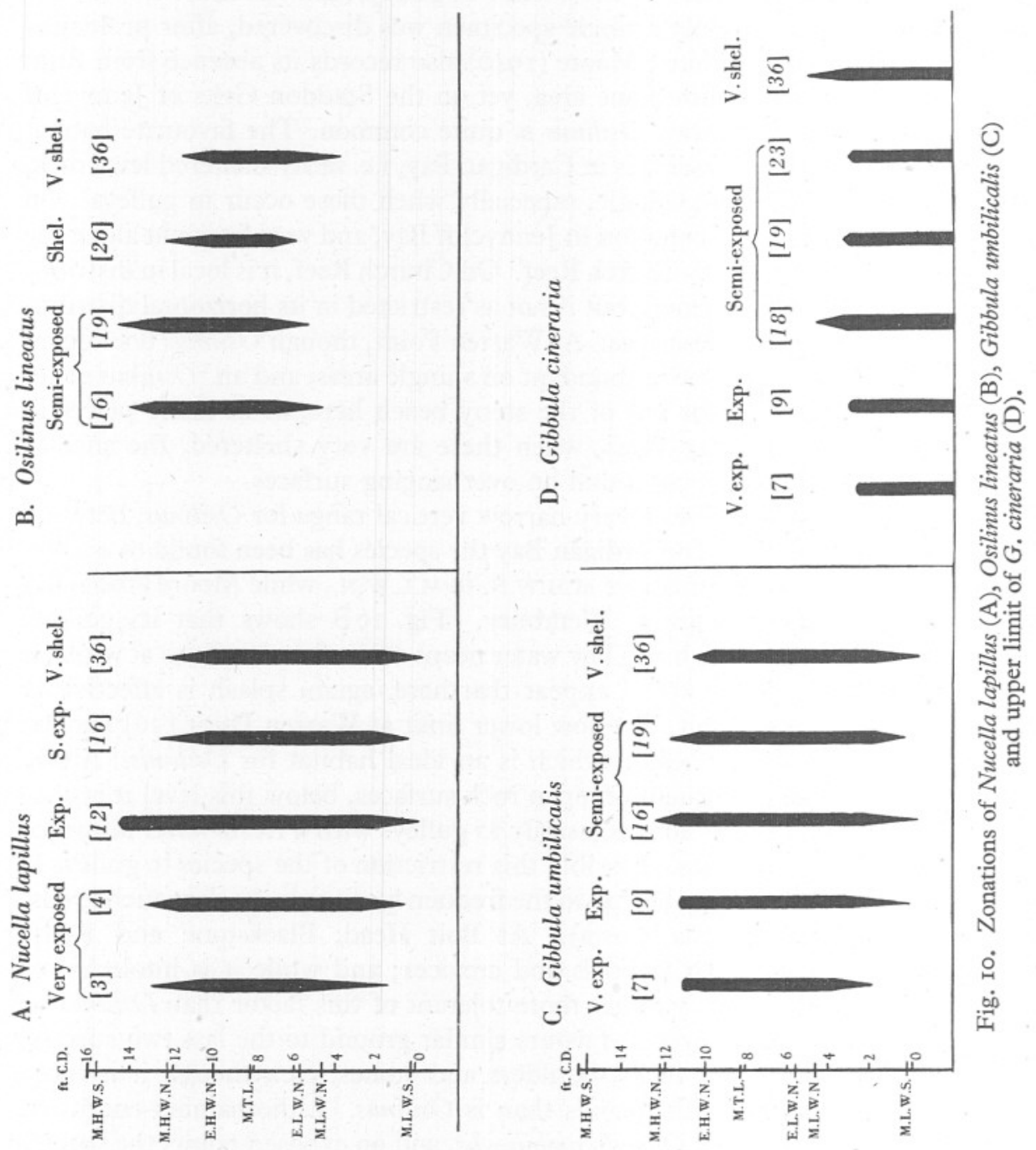

Gibbula cineraria (L.). This is absent or extremely rare at exposed points such as Bolt Head, Blackstone, Reny, and Queener Point, but may be fairly common in more sheltered localities, with the exception of Tinside and Wilderness Point. Its favourite habitat is stony gulleys near low-water mark, where it commonly occurs under the stones. Specimens have also been taken 
on rock under weed, e.g. in the Laminarian zone at Fort Charles, and in the Himanthalia zone on the Breakwater.

From the sublittoral Gibbula cineraria extends up to about $3 \mathrm{ft}$. above c.D., while occasionally it was found to M.L.W.N. Except for a single specimen found in a crack as high as $6 \mathrm{ft}$. above C.D., on the south face of the Breakwater, the species was not recorded above M.L.W.N. anywhere (Fig. IOD).

Nucella lapillus (L.). Nucella, though it is not tolerant of heavy surf, may be quite common even on exposed headlands provided local shelter is available; thus at Blackstone Point the snail is present in appreciable numbers in the deep crevices between the steep ridges of slate. Yet, at North Point, where surf action is considerably less intense than it is at Blackstone, the species is not at all common; presumably this is due to the smoother contours of the rock and the absence of deep cracks and fissures in the felsite strata. Normally Nucella is not over-fond of a thick cover of weed (e.g. at Warren Point), possibly because of the paucity of barnacles (one of its main articles of diet) in such areas, yet at North Point it is curious to find a larger number of the snails under clumps of weed than on neighbouring bare rock. It appears that the shelter afforded by weed, on such a level beach as North Point, may be important. Except in sheltered conditions Nucella is not favoured by steep or vertical faces, but is frequently found in groups on such faces when they face away from the sea; and as the writer has already suggested in Cardigan Bay, there is some indication that, at the top of its distribution, Nucella may seek such surfaces partly at least because of their shade. This species, again, is poor on the Tinside-West Hoe limestone rocks and on Wilderness Point, though in the latter case the paucity of barnacles may be partially responsible. It is not particularly well represented in Jennycliff Bay either, though barnacles and local shelter are both available here.

The vertical zonation of Nucella is depicted in Fig. IoA. The upper limit of the species in quantity lies between E.H.W.N. and M.H.W.N. at most places, but in cracks and fissures on the landward faces of the low-tide reefs at Wembury [12] it occurs up to between M.H.W.N. and M.H.W.S. in numbers. At Warren Point [36], with decreased splash, Nucella is common as high as E.H.W.N. only, but even here it is occasional to M.H.W.N. The lower level of abundance lies in the M.L.W.N.-M.L.W.S. region, except at Blackstone Point [3]; here the rock configuration changes in the neighbourhood of E.L.W.N., and below this level local shelter (crevices, etc.) is infrequent, so that Nucella too is infrequent. Moore (1938) states that Nucella extends to below low water, and it has been definitely recorded to below M.L.W.s. at Church Reef and Warren Point. Comparing Figs. Io A and 6A it will be noted that the zone of abundance of the gastropod lies, in all instances, within the Balanoid zone.

Patella vulgata $\mathrm{L}$. One of the most ubiquitous animals on the shore, this species ranges from conditions of extreme exposure to those of extreme shelter from surf. Yet it does not particularly favour the thick weed zones of 
sheltered localities, and where weed is profuse limpets are generally most numerous on bare protruding peaks and ledges. Hatton (1938) describes a denser settling of Patella on exposed faces than on sheltered ones, and it is possible that the filtering effect of the algal fronds is important in this respect during the time of settling. Moreover, where weed is thick (e.g. at Wilderness Point), the underlying rock is frequently coated with a layer of silt, smaller algae, sponges, and hydroids, forming a dense mat. Such a substratum is shunned by Patella, which is restricted to areas of barer rock. On very wavebeaten slopes (e.g. the seaward peaks of Church Reef), the competition between Patella and barnacles for space is often very noticeable. Where barnacles extend over practically the whole of the available space (even over the limpet shells themselves) Patella is almost invariably represented by small individuals only; larger shells are found only where barnacles are less dense. This, too, is commented upon by Hatton (1938) who, in addition, has observed a denser settling of limpet larvae on bare or artificially-denuded surfaces, than on those thickly covered with barnacles. The same worker describes experiments which demonstrate that the size of Patella is limited by the density of the surrounding barnacle population. With regard to rock slope and texture, $P$. vulgata is very tolerant; it occurs on the roughest rocks and on smooth pebbles; it is frequent on all angles of slope, including overhangs, and may even exist on very small stones where these are not subject to much movement (e.g. at Warren Point).

$P$. vulgata definitely persists to below M.L.W.S., but does not appear to reach E.L.w.S.; however, it occurs lower than the lower limit of $2 \mathrm{ft}$. above C.D. described for it by Colman (1933). Just above M.L.W.S. there is some evidence of its dying out in numbers, and Patella athletica becomes the dominant limpet on exposed rocks at such levels. With regard to the upper limit of $P$. vulgata, Orton (1929) considers that the orientation of the rock surface, the height of splash, the latitude of the locality, and the epoch of the day at which low springs occurs, are all important. Within the geographical limits of the present survey the last two factors are constant, and variations in the upper limit of the species can be ascribed to variations in the first two influences. It is often difficult to disentangle these two effects, for usually south-facing surfaces receive both maximum splash and maximum illumination, one factor tending to raise, the other to lower, the upper limit of distribution. In Fig. II is presented a selection of data arranged to illustrate the effects both of splash and shade. On south faces at Warren Point [36], on sheltered south faces at Jennycliff, and on similar rocks in Wembury Bay [32], $P$. vulgata occurs only to just below M.H.W.N. in the open, and is common only from E.H.W.N. down. These localities are represented in the centre of the text-figure. Proceeding to the left of this figure, all the localities are south-facing, and the illumination factor is therefore constant. Exposure to wave action, and the amount and height of splash are increasing, however, and it is obvious that the upper limit of $P$. vulgata is rising, until, on the seaward reefs of Church Reef [6], the 
Illuminated surfaces

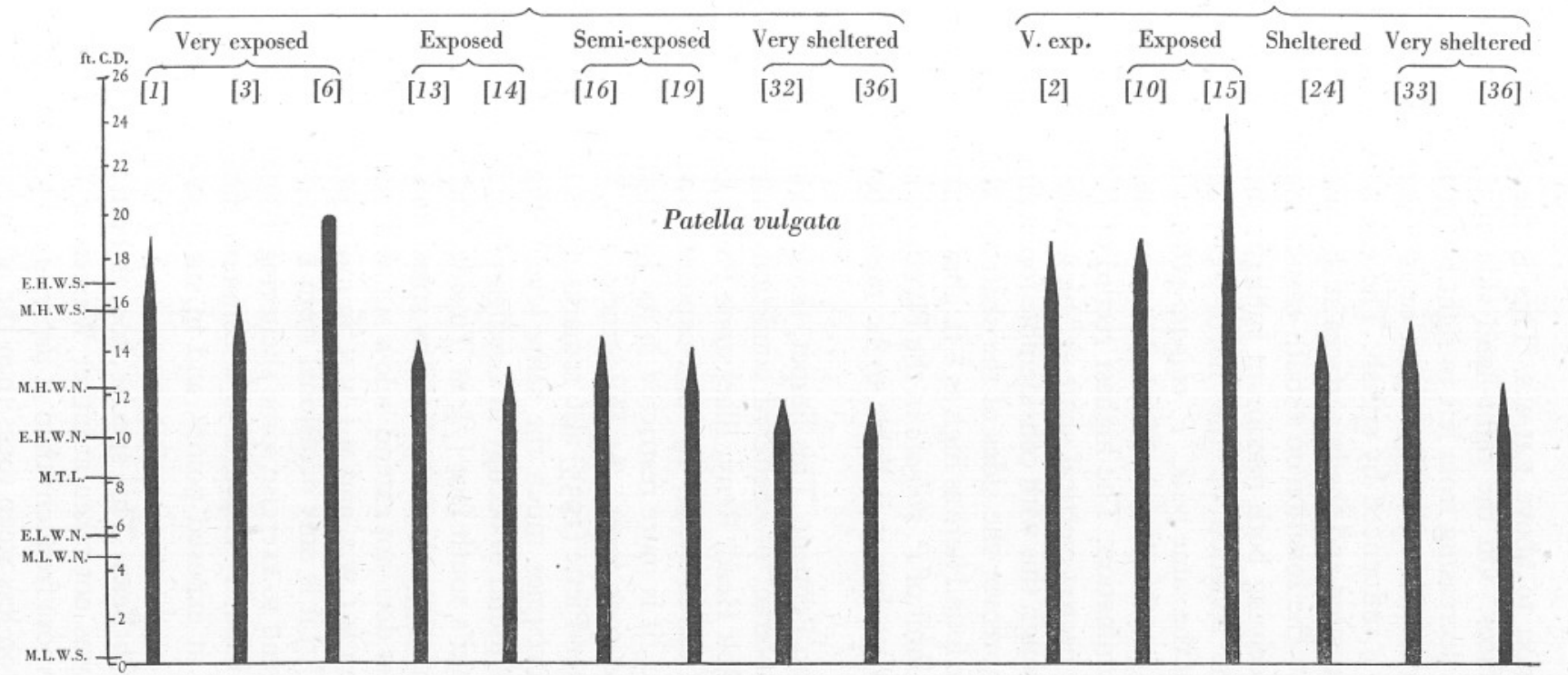

Fig. II. Variations in the upper limit of distribution of Patella vulgata under different conditions of exposure to wave action and illumination. 
species is common to above E.H.w.S. This is the effect of splash on fully illuminated surfaces. On the right-hand side of the figure surf action and splash are again decreasing from left to right but at all these localities $P$. vulgata is either situated on a shady aspect or is covered by weed. Here again the upper limit is influenced by splash. The effect of shade may be seen by comparing illuminated and shady surfaces at the same locality. Column [3] in Fig. II represents the zonation on a south-east-facing rock at Blackstone Point, i.e. a surface receiving both maximum sunlight and maximum wave action; column [10] the zonation on the north-west, and therefore shaded and sheltered, face of the same peak. $P$. vulgata extends almost $4 \mathrm{ft}$. higher on this north-west face, i.e. the absence of splash is more than compensated for by the reduction in illumination. The highest record of $P$. vulgata made during the survey was in a narrow vertical shaft or 'blow-hole' in Wembury Bay [15]; water rushes through this with considerable force, and splash is experienced to great heights, moreover the sides of the shaft are almost perpetually shaded, and limpets were found here as high as $8 \mathrm{ft}$. above E.H.w.S. Generally speaking, then, the upper limit of $P$. vulgata in the Plymouth neighbourhood, lies in the region of M.H.w.N., but it is liable to be raised by shade, weed-cover, and splash.

Patella depressa Pennant. This limpet, though commonly taken during the survey, is less tolerant of sheltered conditions than $P$. vulgata, and is best represented at Bolt Head, Reny, Blackstone Point, Queener Point, and on the outer reefs of Church Reef. In semi-exposed localities such as Jennycliff, North Point, etc., it is more restricted in its distribution, occurring locally on vertical, exposed rock faces. At Wilderness and Warren Points it was not recorded. Fischer-Piette (1935) also remarks on its need for exposure to surf.

The species occupies much the same levels (Fig. I2A) in the Plymouth locality as it was found to occupy in Cardigan Bay; it extends up to M.H.w.N. on the Breakwater's south face [7], at Tinside, and in Jennycliff Bay, but at Bolt Head [1] this upper limit is raised by splash to E.H.w.s. The lower limit is vague, $P$. depressa does not extend below M.L.W.s. anywhere, and it dies out in numbers between M.L.W.S. and M.L.W.N. in most places. On the south face of the Breakwater [7] it is only occasional from E.L.W.N. down, as the protective blocks in front tend to exercise some sheltering influence on the lower part of this slope. As usual $P$. depressa is a common inhabitant of lithothamniaencrusted pools at exposed points, and in such pools it may be common to above E.H.W.S.

Patella athletica Bean. This species, too, is best on wave-beaten reefs and headlands, and was not taken at either Warren or Wilderness Points. However, it is rather more frequent than P. depress $a$ at Fort Charles; moreover, it is generally found on less steep rocks than the other, giving the impression that here, as in Cardigan Bay, it is somewhat less demanding of surf than P. depressa. Fischer-Piette (1935) is inclined to adopt the opposite view. 
$P$. athletica is characteristic of exposed reefs on the lower shore, where fucoids are poor or absent and Corallina is the chief alga, but it has also been found in shaded overhangs. In lithothamnia-encrusted pools it is common to above high water, and in such pools it is usually more frequent than either Patella vulgata or $P$. depressa.

Whenever it occurs, $P$. athletica is common down to the lowest level examined. The upper limit (Fig. I2 B) is again affected both by splash and shade; on very exposed surfaces it may reach almost to M.T.L., on more sheltered reefs it extends as high as M.L.W.N. only, while under overhangs it was occasionally taken above M.T.L. as in Cardigan Bay.

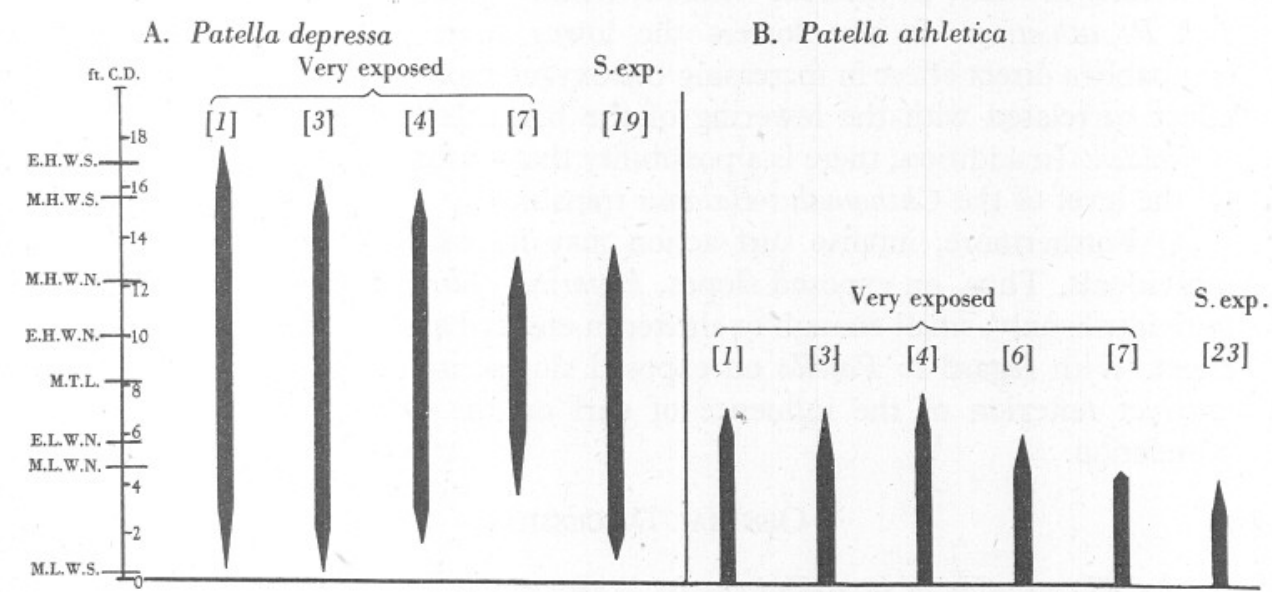

Fig. I2. Zonation of Patella depressa (A) and upper limit of P. athletica (B).

\section{Discussion on the Distribution of the Fauna}

It has been shown that, for algae, surf acts chiefly, $(a)$ as a presence or absence factor, and $(b)$ as a modifying influence on the extent and position of algal zones. Much the same is true with regard to the fauna:

(I) As a presence or absence factor, wave action determines the density of the population of Chthamalus, Balanus balanoides, Littorina neritoides, Nucella lapillus, Patella vulgata, P. athletica, all of which species favour somewhat exposed conditions. The effect of surf on such animals may be directly concerned with transport of food, larvae, oxygen, etc. (as is probably true for barnacles); or it may be concerned in that it determines the height and frequency of splash and spray (e.g. for Littorina neritoides). With Patella vulgata, Hatton's (1938) experiments have shown that heavy surf favours a denser settling of larvae; the same is probably true for $P$. depressa and $P$. athletica, though for these two limpets there appears to be an additional effect restricting them to exposed localities. The nature of this influence is unknown. 
For Nucella the effect of surf is indirect, in that it provides an abundant barnacle population which the gastropod can utilize for food; for barnacles themselves, too, surf has an indirect as well as a direct effect, in that it tends to remove algal competition. For Littorina littoralis this effect is reversed, i.e. surf, by discouraging fucoids, also discourages the snail. The adverse influence of excessive wave action on free-living gastropods such as Osilinus, Littorina littorea and Gibbula is, in all probability, a purely mechanical one, tending to knock such animals off the rock and damage their shells.

(2) As a modifying factor on vertical zonation, exposure to surf raises the upper limits of Balanus balanoides, B. perforatus, Chthamalus stellatus, Littorina neritoides, L. rudis, L. littorea, Osilinus, Gibbula, Patella vulgata, $P$. depressa and $P$. athletica. It also lowers the lower limit of Balanus balanoides (probably a direct effect in increasing the oxygenation), of Nucella (an indirect effect correlated with the lowering of the barnacle limits) and of Littorina neritoides. In addition, there is a possibility that surf may have some influence on the level of the Chthamalus-Balanus transition.

(3) Furthermore, intense surf action may impose a limit on the size of individuals. Thus, on exposed slopes, Littorina rudis is represented by small individuals only, small enough to shelter in empty barnacle shells, i.e. a direct effect. With regard to Patella on exposed slopes, its reduction in size is an indirect reflexion of the influence of surf on the density of the barnacle population.

\section{GENERAL DisCUSSION}

\section{The relation of intertidal species to percentage exposure to the air}

The figures of Colman (1933, table VI, p. 456) for percentage exposure to the air at different shore levels are here taken as applicable; these are based on the I930 tides, but are not likely to vary greatly from year to year. For comparison with Cardigan Bay I have chosen the landward portion of Church Reef. This locality represents intermediate conditions between the extreme exposure of Bolt Head and Blackstone Point, for instance, and the extreme shelter of Warren and Wilderness Points; as nearly as can be judged, the exposure to surf here is roughly equivalent to that experienced on the Cardiganshire coast; moreover, the results can be compared with those of Colman (1933). Fig. I3 summarizes the zonation of the various species studied on Church Reef, with the percentage-exposure curve superimposed. Table III compares the percentage-exposure limits of the species: (I) on Church Reef (present survey); (2) on Church Reef (according to Colman, 1933)-again the 'splash allowance' has been deducted, and the figures are based on Colman's 'extreme values' (I933, p. 454, tables IV and V); (3) in Cardigan Bay. In addition, (4) the extreme limits to which the species were found anywhere during the South Devon survey are also figured. 
Comparing columns (I) and (2), the advantage of a wide-scale survey over a detailed but local traverse survey is obvious; for practically all the species, excepting Fucus serratus, Littorina littorea, L. littoralis, and Gibbula cineraria, were found to have a wider distribution on Church Reef than appeared from Colman's traverses. Fucus serratus and the two species of Littorina are similarly zoned by both surveys, but Gibbula cineraria was recorded much higher by Colman than by the present worker; and the same is true of the upper limit of Lichina pygmaea.

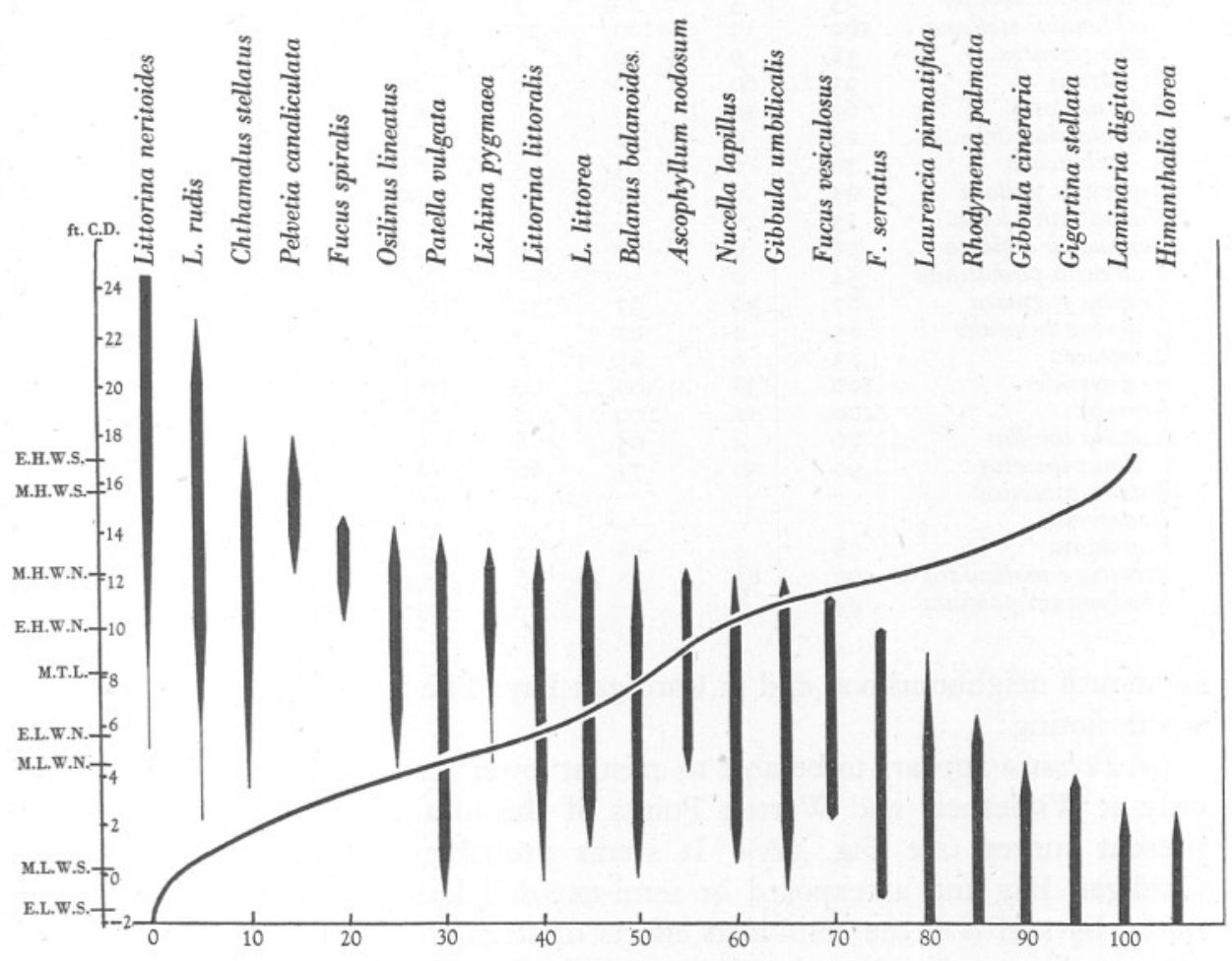

Fig. 13. Zonation of species on the landward portion of Church Reef, Wembury. The curve representing the percentage exposure to the air at different tidal levels is superimposed.

It appears, from a comparison of columns (I) and (4) that, with few exceptions, the plants and animals on Church Reef do not occupy the whole ranges possible to them. Here, however, the factor of exposure to wave action and splash is introduced, and it is obvious that at places like Bolt Head the vertical ranges are widened by this factor.

Comparing columns (3) and (4) it will be seen that, generally speaking, there is a fair degree of similarity between the zonation of littoral species in the 
Table III. Percentage Exposure to the Air of Species in Cardigan Bay, on Church Reef, and in the Plymouth Neighbourhood

\begin{tabular}{|c|c|c|c|c|c|c|c|c|}
\hline \multirow[b]{2}{*}{ Species } & \multicolumn{2}{|c|}{$\underbrace{\text { (I) }}_{(\text {I946) }}$} & \multicolumn{2}{|c|}{$\begin{array}{l}\text { (2) } \\
\text { Church Reef } \\
\text { (Colman) }\end{array}$} & \multicolumn{2}{|c|}{$\begin{array}{l}\text { (3) } \\
\text { Cardigan } \\
\text { Bay }\end{array}$} & \multicolumn{2}{|c|}{$\begin{array}{c}\text { (4) } \\
\text { Plymouth } \\
\text { neighbourhood }\end{array}$} \\
\hline & $\begin{array}{l}\text { Upper } \\
\text { limit } \\
(\%)\end{array}$ & $\begin{array}{l}\text { Lower } \\
\text { limit } \\
(\%)\end{array}$ & $\begin{array}{l}\text { Upper } \\
\text { limit } \\
(\%)\end{array}$ & $\begin{array}{l}\text { Lower } \\
\text { limit } \\
(\%)\end{array}$ & $\begin{array}{l}\text { Upper } \\
\text { limit } \\
(\%)\end{array}$ & $\underset{\substack{\text { Lower } \\
(\%)}}{\text { limit }}$ & $\begin{array}{l}\text { Upper } \\
\text { limit } \\
(\%)\end{array}$ & $\begin{array}{c}\text { Lower } \\
\text { limit } \\
(\%)\end{array}$ \\
\hline $\begin{array}{l}\text { Ascophyllum nodosum } \\
\text { Balanus balanoides }\end{array}$ & 77 & 25 & 75 & 30 & 71 & I5 & 83 & IO \\
\hline Balanus balanoides & 83 & 3 & 80 & 5 & 83 & 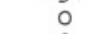 & 96 & 0 \\
\hline Chthamalus stellatus & 100 & I7 & roo & 20 & 100 & 28 & IOO & Io \\
\hline Fucus serratus & 58 & 0 & 60 & 0 & 56 & 0 & 58 & 0 \\
\hline F. spiralis & 93 & 60 & 90 & 70 & 96 & 55 & 94 & 56 \\
\hline F. vesiculosus & 69 & I6 & - & - & 63 & 8 & 83 & 5 \\
\hline Gibbula cineraria & 29 & .0 & 40 & 0 & $2 \mathrm{I}$ & 0 & 33 & 0 \\
\hline G. umbilicalis & .76 & 0 & 65 & 5 & 63 & 2 & 76 & 0 \\
\hline Gigartina stellata & 25 & 0 & 20 & 0 & 26 & 0 & 39 & $\circ$ \\
\hline Himanthalia lorea & I5 & 0 & - & - & - & 一 & $4 \mathrm{I}$ & 0 \\
\hline Laminaria digitata & I8 & 0 & I2 & 0 & 20 & 0 & 25 & 0 \\
\hline Laurencia pinnatifida & 54 & 0 & - & - & 60 & 0 & 56 & 0 \\
\hline Lichina pygmaea & 87 & 30 & 97 & 52 & IOO & 22 & I00 & 33 \\
\hline Littorina littoralis & 85 & 2 & 87 & 7 & $8 I$ & 4 & 85 & 2 \\
\hline L. littorea & 83 & 6 & 85 & 8 & $7 \mathrm{I}$ & 7 & 93 & I \\
\hline L. neritoides & 100 & 38 & 100 & 90 & 100 & 20 & 100 & I3 \\
\hline L. rudis & 100 & 12 & I00 & 60 & IOO & 8 & 100 & 7 \\
\hline Nucella lapillus & 76 & 4 & 65 & 8 & 62 & $\circ$ & 93 & o \\
\hline Osilinus lineatus & 90 & 30 & 75 & 60 & 82 & 22 & 93 & 24 \\
\hline Patella athletica & - & 一 & - & 一 & 42 & 0 & 45 & 0 \\
\hline P. depressa & - & - & - & - & 92 & 0 & 100 & 0 \\
\hline P. vulgata & 98 & 0 & 98 & 12 & 100 & 0 & 100 & 0 \\
\hline Pelvetia canaliculata & 100 & 85 & 98 & 86 & IOO & 87 & IOO & 65 \\
\hline Rhodymenia palmata & 44 & o & - & - & 35 & 0 & 47 & 0 \\
\hline
\end{tabular}

Plymouth neighbourhood and in Cardigan Bay. The following exceptions are worth noting:

(a) Pelvetia appears to be able to exist at lower levels in South Devon, but only at Wilderness and Warren Points of the localities investigated in the present survey (see Fig. 3A). It seems probable that its lower limit in Cardigan Bay and at exposed or semi-exposed localities near Plymouth is raised by surf (i.e. the combined effects of strength of wave shock and frequency of wave shock) as already described. Conditions as sheltered as those at Wilderness and Warren Points are not met with anywhere on the part of the Cardiganshire coast investigated. Moreover, the effect of splash in raising the effective height of tides is important; thus the level of M.H.W.N. at Bolt Head may be almost as damp as E.H.W.N. at Warren Point, and if the lower limit of Pelvetia is determined by some ill-effect of immersion then the effective (as opposed to the predicted) height of tides will be important. At Church Reef, it should be noted, the lower limit of the alga is very similar to that in Cardigan Bay, and here surf effects are more or less equivalent.

(b) The algae Rhodymenia, Gigartina and, to a lesser extent, Laminaria digitata; the barnacle Balanus balanoides, and the limpets Patella depressa and 
P. athletica, all have higher upper limits in the Plymouth neighbourhood than they do in Cardigan Bay. Littorina neritoides and Ascophyllum have lower lower limits. Yet, comparing the semi-exposed locality of Church Reef with the coast of West Wales, the discrepancies are less marked. It has already been shown that surf exerts an elevating effect on such upper limits (and a depressing effect on the lower limit of Littorina neritoides), and the differences are probably "due to the extreme exposure to surf encountered at Bolt Head, Blackstone, etc., which is unparalleled anywhere in Cardigan Bay. The same is possibly true with regard to the upper limits of Fucus vesiculosus and Ascophyllum. While these are only able to tolerate a certain maximum of surf, which is often exceeded in Cardigan Bay, it is possible to discover their existence in local shelter (fissures, etc.) at exposed points near Plymouth, where they receive more splash, and their environment is considerably damper, than it is anywhere on the Cardiganshire coast, at an equivalent level.

(c) The lower limit of Chthamalus is interesting. Moore \& Kitching (1939) describe how, proceeding eastward along the south coast, and northwards along the west coast of Britain, this barnacle not only tends to die out in numbers, but becomes less tolerant of conditions on the lower beach. This, these workers suggest, is due to the fact that, as certain factors (lack of Atlantic water?) become critical for the barnacle, it becomes less tolerant of the ill-effects of immersion. This explains the difference in lower level of Chthamalus in Cardigan Bay from that in the Plymouth neighbourhood.

Apart from these exceptions, the zonations of Fucus spiralis, F. serratus, Laurencia pinnatifida, Littorina rudis, L. littoralis and Patella vulgata, are very similar in both localities. Thus, out of twenty-two species common to the two surveys, no fewer than sixteen are either similar in their zonation at both places or the differences can be explained by the known facts of surf effects, while the differences for Chthamalus are also explicable. The exceptions are: Osilinus, Nucella, Gibbula umbilicalis, G. cineraria and Littorina littorea. All these appear to be somewhat more tolerant of exposure to the air in the Plymouth neighbourhood than they are in West Wales, and since the differences in the upper limits of these species are also manifested under the semiexposed (to surf) conditions of Church Reef, splash effects can hardly be held to account for this. No satisfactory explanation or suggestion can, as yet, be put forward.

\section{Critical Levels}

Certain levels have been shown (Evans, 1947) to be more critical than others in connexion with the distribution of intertidal plants and animals in Cardigan Bay. These are:

(I) Between M.L.W.S. and E.L.W.S., where the majority of intertidal species achieve their lower limits.

(2) Between M.L.W.S. and M.L.W.N., which marks the lower limits of certain other intertidal species. 
(3) Just above M.L.W.N., where several sublittoral species reach their upper limits of penetration into the intertidal zone.

(4) Just below M.H.W.N., marking the upper limit of one set of intertidal species.

(5) Between M.H.w.S. and E.H.w.S., where a further set of intertidal plants and animals achieve their upper limits.

These were compared with levels described by Colman (I933) as critical for a similar set of species on Church Reef, and the points of difference were discussed. During the present work the writer has attempted to recognize such levels, not only on Church Reef, but also at the other localities studied. However, at many stations (e.g. Bolt Head, Blackstone, Reny, etc.) so many species are unrepresented or occur very infrequently that such localities are best omitted from the discussion. Sufficient data are available for North Point, Queener Point, Jennycliff Bay, and Wilderness Point, and since these display a fair range in conditions of shelter and exposure to surf, the discussion will be based on these. The method used by Colman (1933, p. 463) to elucidate critical levels has been followed, i.e. the number of upper and lower limits occurring between $-2 \mathrm{ft}$. and $+\mathrm{I} \mathrm{ft}$. C.D., between $-\mathrm{I} \mathrm{ft}$. and $+2 \mathrm{ft}$. C.D., between 0 and +3 ft. C.D., etc., was calculated for each station. Graphs were drawn in the way that Colman describes, and the peaks of such graphs were taken to mark critical levels. The results are summarized in Fig. I4; the brackets embrace the levels (e.g. $+2 \mathrm{ft}$. and $+6 \mathrm{ft}$. c.D.) between which the various maxima occur. The Cardigan Bay results are included in the same figure, also results achieved by interpreting Colman's (I933) data for Church Reef (without a splash allowance). The numbers (I) to (5) are equivalent at all localities.

It will be observed that levels (I) and (2), which are separate entities in Cardigan Bay, at Church Reef, North Point and Wilderness Point, are not distinguishable from each other at either Queener Point or Jennycliff; neither do they appear as separate levels from Colman's survey of Church Reef. At the first two localities in Fig. I4 (i.e. Cardigan Bay and Church Reef), these levels mark the lower limits of the following intertidal species.

Level (I): Patella vulgata, Balanus balanoides, Littorina littoralis, L. lit- . torea, Gibbula umbilicalis, Nucella lapillus and Fucus serratus.

Level (2): Littorina rudis, Chthamalus stellatus, Lichina pygmaea, Ascophyllum nodosum, Fucus vesiculosus, and Osilinus lineatus. (In Cardigan Bay, Littorina neritoides also ends within this region, at Church Reef it ends slightly above it.)

At Queener Point there is a single maximum, marked on Fig. I4 as (I and 2). Within the levels enclosed by this bracket all the species represented in levels (I) and (2) of Cardigan Bay achieve their lower limits, with the exception of Littorina littorea, L. littoralis, Ascophyllum, Fucus serratus and Osilinus, all of which are either totally absent from Queener Point or occur too infrequently 
to zone. Thus the merging of (I) and (2) into a single critical level at this locality is due to the lowering, by intense surf action, of the lower limits of Chthamalus, Littorina rudis and L. neritoides; so that the two separate critical levels cannot be distinguished, and there occurs a single maximum between $-\mathrm{I}$ ft. and +3 ft. C.D.

At North Point we appear to have what is an intermediate stage between Cardigan Bay and Queener Point. Here, (I) and (2) overlap; again due to the depression of the lower limits of Chthamalus and Littorina rudis, and also of Osilinus; but Littorina neritoides achieves its lower limit higher up.

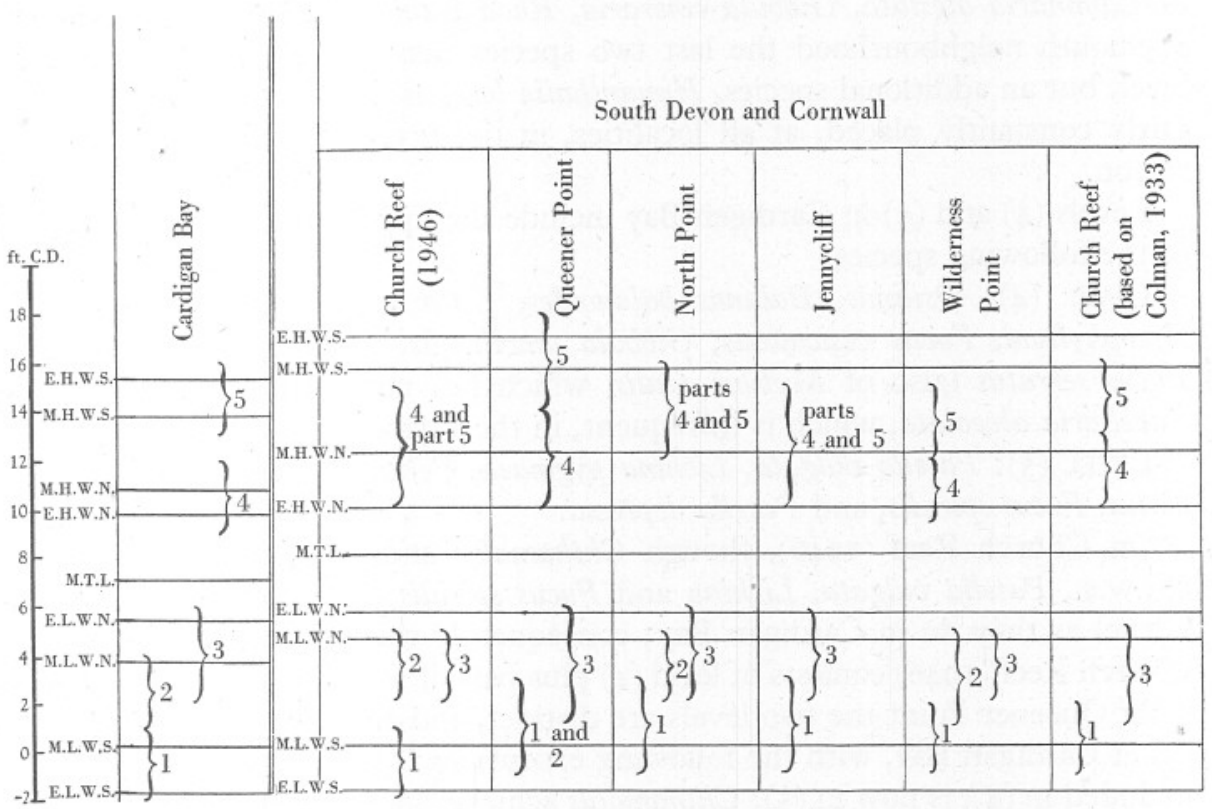

Fig. I4. The position of 'critical levels' in Cardigan Bay and in localities in South Devon and Cornwall. For explanation, see text.

From the four examples: Cardigan Bay, Church Reef, North Point, and Queener Point, then, it would appear that heavy surf action, by permitting certain species to extend their lower limits of distribution, leads to the appearance of a single critical level marking the lower limit of intertidal species instead of two such levels.

In Jennycliff Bay, however, level (I) does not represent a combination of (I) and (2); here the lower limits of Littorina rudis, L. neritoides, and Osilinus are raised by shelter, Lichina is unrepresented. Moreover, though Ascophyllum and Fucus vesiculosus end in the M.L.W.N. region, the number of limits becomes spread out, and no clear maximum can be recognized except the one 
just above M.L.W.S.g i.e. level (I). Thus, in Jennycliff Bay, critical level (2) is unrepresented.

At Wilderness Point an overlap occurs, due to the raising (by shelter) of the lower limits of Littorina rudis, Chthamalus, Ascophyllum, and Fucus vesiculosus, and to the absence of Osilinus and Lichina.

With regard to the lower limit of intertidal species, then, either two maxima or one may be recognized; but the M.L.W.N.-M.L.W.S. region is definitely critical for such species, unless a few are permitted to penetrate beyond M.L.W.S. under the influence of strong surf action.

Level (3) in Cardigan Bay marks the upper limit of sublittoral species such as Laminaria digitata, Gibbula cineraria, Rhodymenia and Gigartina. In the Plymouth neighbourhood the last two species may extend up beyond this level, but an additional species, Himanthalia lorea is introduced. This level is fairly constantly placed, at all localities, in the M.L.W.N. to M.L.W.N. - I ft. region.

Levels (4) and (5) in Cardigan Bay include the upper limits of distribution of the following species:

Level (4): Osilinus, Balanus balanoides, Littorina littorea, L. littoralis, Ascophyllum, Fucus vesiculosus, Gibbula umbilicalis, Nucella, Laurencia and Fucus serratus (also of Mytilus edulis, which has not been studied, and of Sabellaria alveolata, which is infrequent, in the Plymouth neighbourhood).

Level (5): Patella vulgata, Lichina pygmaea, Pelvetia canaliculata, Chthamalus, Fucus spiralis, and Patella depressa.

On Church Reef (1946), though Chthamalus and Pelvetia extend above E.H.w.S., Patella vulgata, Lichina and Fucus spiralis do not exist to as high a level as they do in Cardigan Bay; consequently this single critical level at Church Reef (1946) consists of level (4) plus part of level (5) of Cardigan Bay.

At Queener Point the two levels are distinct, and are equivalent to (4) and (5) of Cardigan Bay, with the following exceptions: Osilinus, instead of being included in (4), is now in (5); Chthamalus achieves its upper limit higher than (5); and Littorina littorea, L. littoralis, Ascophyllum and Fucus serratus are absent due to the violence of surf experienced at Queener Point.

The upper critical level at North Point does not include the upper limit of Chthamalus, which ends above it; of Fucus vesiculosus, F. serratus or Laurencia, which end below it; or of Ascophyllum, which is too infrequent to zone at this locality. Thus it represents parts of (4) and parts of (5).

The same is true of the single level in Jennycliff Bay. Chthamalus and Pelvetia end above it; Laurencia ends below it; while Lichina is unrepresented.

At Wilderness Point the two levels are equivalent to those of Cardigan Bay, with the following exceptions: Osilinus is absent; Littorina littorea is infrequent and was not included in the results, neither was Laurencia; L. littoralis (under the cover of Pelvetia) extends upshore to end in (5) and not in (4); the upper limit of Littorina rudis is lowered by the sheltered conditions, and comes to lie 
in (5) instead of well above it as it does in more exposed localities. However, the levels are more or less equivalent, and have been numbered accordingly.

Summarizing these results, it would appear that, while generalizations can be made with regard to certain levels on the shore being more critical than others for intertidal plants and animals, any arbitrary method of graphing specific limits and deriving critical levels from these graphs (as Colman, I933, and the present worker have done) will inevitably yield somewhat inconsistent results at different localities. Both the number and type of species studied will be important; and any local modifications or variations in environmental factors are likely to have varying effects on the upper and lower limits of different species, and so to cause variation in the position of critical levels at different localities. The factor of exposure to wave action is obviously of great importance in this respect; there is often a considerable difference between the 'predicted' height of tides and their 'actual' or 'effective' height, which is determined by the amount of wave action and splash. Zoning species on a basis of predicted tidal levels will inevitably yield different results at different localities; and the difficulty is to evolve some method of assessing the actual, effective height of tides at localities exposed to varying degrees of surf action. Other modifying factors which may upset the scheme of vertical zonation and displace the critical levels are: rock slope, the presence of shading influences, the presence of thick algal cover, etc. Nevertheless, despite the discrepancies in the positions of critical levels at different places along the coast, certain generalizations can be made:

(a) The region between M.L.W.S. and M.L.W.N. is critical in the sense that the majority of intertidal plants and animals reach their lower limits here. Often two sets of such species may be distinguished: (I) those for which the neighbourhood of M.L.W.S. is critical, and (2) those which reach their lower limits in the M.L.W.N. region.

(b) While certain sublittoral species may succeed in penetrating into the littoral region, these generally extend only as high as a level just below M.L.W.N.

(c) Levels between E.H.W.N. and M.H.W.S. are critical for intertidal species in the sense that many of them reach their upper limits here; though some, normally limited in the M.H.W.N.-M.H.W.S. region, may be elevated by splash to above this.

(d) It is very clear, at all the localities without exception, that the region of the shore between E.L.W.N. and E.H.W.N. is the least critical for intertidal plants and animals. Here, not only are the relative times of submergence and emergence (together with the change in environmental conditions correlated with these states) regular, but the factor of 'non-tidal' exposure to the air is not introduced.

Colman (I933) and Chapman (I94I) both discuss the significance of critical levels on the shore and the possible factors which may account for them. It would appear that far too little is known of the requirements of individual 
species (e.g. the relative periods of submergence and emergence which they require, or are able to withstand), and a study of these, correlated with the analysis of tidal data, is likely to prove the most promising approach to the problem.

\section{SUMMARY}

The work includes an investigation of the intertidal distribution of several species previously studied in Cardigan Bay. Twelve localities in the neighbourhood of Plymouth were selected for study, showing a range from conditions of extreme exposure to surf action to conditions of maximum shelter. The main features of rock configuration and surf action at the different localities are briefly described.

The method of investigation is described, and results obtained for the zonation of the fucoids on Church Reef are compared with the resuits of Colman (1933). It is concluded that the method of survey adopted in the present work yields results of a high degree of accuracy.

The horizontal and vertical distributions of the flora are described and related to the intensity of surf action. This is followed by a discussion of the effects of wave intensity and wave frequency on the distribution of algae in general. The importance of the frequency of wave shock in the mid-tidal region of the shore, and its influence on algal colonization, is stressed. An attempt is made to arrange the algae studied in order of decreasing tolerance of surf.

The distribution of the selected species of animals at the different localities is described; and a discussion follows on the effect of wave action as a presence or absence factor in horizontal distribution, and as a modifying factor on vertical zonation. The effect of surf on the size of individuals of certain species is also commented upon.

The relation of the plant and animal species to different percentage exposures to the air at different shore levels is discussed. Results obtained from an extensive survey of Church Reef, Wembury, are compared with those obtained from Colman's (1933) traverse survey of the same area, and with the Cardigan Bay results. The percentage air-exposure limits of species in the Plymouth neighbourhood are also compared with similar limits in Cardigan Bay. It is concluded that there is a great degree of similarity in intertidal zonation at the two localities, though certain species appear to be more tolerant of exposure to the air in South Devon than they are on the Cardiganshire coast.

The existence of 'critical levels' for intertidal species in Cardigan Bay and at five localities near Plymouth is investigated. It is shown that the position of such levels changes in relation to local variations in surf action, rock configuration, illumination, etc.; nevertheless the existence of critical levels is an actuality. Generally speaking, the following regions of the shore may be 
described as more critical than others for littoral plants and animals: (a) from M.L.W.S. (or just below this) to M.L.w.N.; (b) just below M.L.W.N.; (c) from E.H.W.N. to M.H.W.S. The least critical levels on the shore are between E.L.W.N. and E.H.W.N.

The writer wishes to thank Prof. T. A. Stephenson for his help and criticism of the manuscript, and to acknowledge a grant from the Royal Society which made the work possible.

\section{REFERENCES}

Admiralty Tide Tables, Sect. A, Pts. I and II. I937-46. H.M. Stationery Office, London.

Børgesen, F., I908. The algal vegetation of the Faeröese coasts. Botany of the Faeroes, Pt. III, pp. 683-834.

Chapman, V. J., I94I. Zonation of marine algae on the Sea-shore. Proc. Linn. Soc. Lond., Vol. I54, pp. 239-53.

Colman, J., I933. The nature of the intertidal zonation of plants and animals. Fourn. Mar. Biol. Assoc., Vol. 18, pp. 435-76.

Cotron, A. D., I9I2. Clare Island Survey. Marine Algae. Proc. Roy. Irish Acad., Vol. 3I, Pt. I5, pp. I-I78.

DAvid, H. M., I94I. The ecology of marked areas on the Aberystwyth shore. Ph.D. Thesis, University College of Wales, Aberystwyth.

Evans, R. G., I947. The intertidal ecology of Cardigan Bay. Fourn. Ecol., Vol. 34, pp. 273-309.

Fischer-Piette, E., I933. Sur la répartition du cirripède Balanus balanoides le long des côtes françaises et anglaises de la Manche. Assoc. franc. p. l'avanc. Sci. Chambéry, I933, pp. 476-80.

— I935. Systématique et biogéographie-Les Patelles d'Europe et d'Afrique du Nord. Fourn. Conchyl., Vol. 79, pp. I-66.

- 1936. Études sur la biogéographie intercotidale des deux rives de la Manche. F. Linn. Soc., London, Zool., Vol. 40, pp. 181-272.

GrBB, D. C., I938. The marine algal communities of Castletown Bay, Isle of Man. fourn. Ecol., Vol. 26, pp. 96-II7.

Gislén, T., I930. Epibioses of the Gullmar Fjord. I. A study in Marine Sociology. Kristinebergs Zool. Stat., I877-1927, Uppsala. No. 3, I23 pp.

GRuBb, V. M., I936. Marine algal ecology and the exposure factor at Peveril Point, Dorset. Fourn. Ecol., Vol. 24, pp. 392-423.

Hatton, H., I938. Essais de bionomie explicative sur quelques éspèces intercotidales d'algues et d'animaux. Ann. Inst. Oceanogr., T. I7, pp. 24I-348.

Kitching, J. A., I935. An introduction to the ecology of intertidal rock surfaces on the coast of Argyll. Trans. Roy. Soc. Edin., Vol. 58, pp. 35I-74.

Lysaght, A. M., I94I. The biology and trematode parasites of the gastropod Littorina neritoides (L.) on the Plymouth breakwater. Fourn. Mar. Biol. Assoc., Vol. 25, pp. 4I-67.

Marine Biological Association, i93i. Plymouth Marine Fauna (2nd ed.).

Moore, H. B., I935a. The biology of Balanus balanoides. IV. Relation to environmental factors. Fourn. Mar. Biol. Assoc., Vol. 20, pp. 279-307.

I935b. The biology of Balanus balanoides. V. Distribution in the Plymouth area. fourn. Mar. Biol. Assoc., Vol. 20, pp. 70I-Io. 
MOORE, H. B. I938. The biology of Purpura lapillus. III. Life history and relation to environmental factors. Fourn. Mar. Biol. Assoc., Vol. 23, pp. 67-74.

- 1940. The biology of Littorina littorea. Part II. Zonation in relation to other gastropods on stony and muddy shores. Fourn. Mar. Biol. Assoc., Vol. 24, pp. 227-37.

Moore, H. B. \& Kitching, J. A., I939. The biology of Chthamalus stellatus (Poli). fourn. Mar. Biol. Assoc., Vol. 23, pp. 52 I-4I.

NAYLOR, G. L., I930. Notes on the distribution of Lichina confinis and L. pygmaea in the Plymouth district. Fourn. Mar. Biol. Assoc., Vol. 16, pp. 909-18.

Orton, J. H., I929. Observations on Patella vulgata. Part III. Habitat and Habits. Fourn. Mar. Biol. Assoc., Vol. 16, pp. 277-88.

ReEs, T. K., I935. The marine algae of Lough Ine. Fourn. Ecol., Vol. 23, pp. 69-I33.

Stephenson, T. A., I94I. The causes of the vertical and horizontal distribution of organisms between tide-marks in South Africa. Proc. Linn. Soc. Lond., Vol. I54, pp. 219-32.

WALTON, C. L., I915. The distribution of some littoral Trochidae and Littorinidae in Cardigan Bay. Fourn. Mar. Biol. Assoc., Vol. 10, pp. I14-22.

ZANEVELD, J. S., I937. The littoral zonation of some Fucaceae in relation to desiccation. Fourn. Ecol., Vol. 25, pp. 43I-68. 